\title{
Prognostic values of the mRNA expression of natural killer receptor ligands and their association with clinicopathological features in breast cancer patients
}

\author{
Ali Abouelghar ${ }^{1}$, Reem Hasnah ${ }^{2}$, Ghina Taouk ${ }^{3}$, Mohamad Saad $^{4}$ and Manale Karam ${ }^{5}$ \\ ${ }^{1}$ Cancer Research Center, Qatar Biomedical Research Institute, Hamad Bin Khalifa University, Qatar Foundation, Doha, Qatar \\ ${ }^{2}$ Department of Biological Sciences, Carnegie Mellon University in Qatar, Doha, Qatar \\ ${ }^{3}$ Cancer Research Center, Qatar Biomedical Research Institute, Hamad Bin Khalifa University, Qatar Foundation, Doha, Qatar \\ ${ }^{4}$ Qatar Computing Research Institute, Hamad Bin Khalifa University, Doha, Qatar \\ ${ }^{5}$ Cancer Research Center, Qatar Biomedical Research Institute, Hamad Bin Khalifa University, Qatar Foundation, Doha, Qatar \\ Correspondence to: Manale Karam, email: mdoldur@hbku.edu.qa \\ Keywords: natural killer cells; breast cancer; NK receptor ligands; Kaplan-Meier plotter; prognosis \\ Received: February 12, $2018 \quad$ Accepted: May 14, $2018 \quad$ Published: June 05, 2018 \\ Copyright: Abovelghar et al. This is an open-access article distributed under the terms of the Creative Commons Attribution \\ License 3.0 (CC BY 3.0), which permits unrestricted use, distribution, and reproduction in any medium, provided the original author \\ and source are credited.
}

\section{ABSTRACT}

Background: Natural killer (NK) cells are lymphocytes of the innate immune system that have potent cytotoxic activity against tumor cells. NK cell recognition and activity towards cancer cells are regulated by an integrated interplay between numerous inhibitory and activating receptors acting in concert to eliminate tumor cells expressing cognate ligands. Despite strong evidence supporting the role of NK cells in breast cancer (BC) control, BC still develops and progresses to form large tumors and metastases. A major mechanism of BC escape from NK immunity is the alteration of the expression of NK receptor ligands. The aim of this study was to determine whether NK receptor ligands' mRNA expression might influence prognosis in BC patients and whether these effects differ by molecular subtypes and clinicopathological features.

Methods: We used the KM plotter platform to analyze the correlation between mRNA expression of 32 NK receptor ligands and relapse-free survival (RFS) and overall survival (OS) in 3951 and 1402 BC patients, respectively. The association with tumor subtypes and clinicopathological features was determined. BC samples were split into high and low expression groups according to the best cutoff value and the two patient cohorts were compared by Kaplan-Meier survival plots. The hazard ratios with $\mathbf{9 5 \%}$ confidence intervals and log rank $\boldsymbol{P}$ values were calculated and FDRadjusted for multiple testing correction. The data was considered to be statistically significant when FDR-adjusted $P$ value $<0.05$.

Results: High mRNA expression of around $80 \%$ of ligands for NK activating and inhibitory receptors associated with better RFS, which correlated with longer OS for only about half of the NK-activating ligands but for most NK-inhibitory ligands. Also, five NK-activating ligands correlated with worse prognosis. These prognostic values were differentially associated with the BC clinical criteria. In addition, the favorable prognostic influence of NK-activating ligands' upregulation, as a whole, was mainly significantly associated with HER2-positive and basal-like subtypes, lymph node positive phenotype, and high-grade tumors.

Conclusions: NK receptor ligands appear to play an important role in defining BC patient prognosis. Identification of a group of patients with worse prognosis 


\section{expressing high levels of NK-activating ligands and low levels of NK-inhibitory ligands makes them ideal potential candidates for NK-based immunotherapy to eliminate residual tumor cells, prevent relapse and improve patient survival.}

\section{INTRODUCTION}

Breast cancer $(\mathrm{BC})$ treatment has experienced several changes in the past decades due to the discovery of specific prognostic and predictive biomarkers that allowed its classification and enabled the application of more individualized therapies to the different molecular subgroups [1-4]. Among these biomarkers, steroid hormone receptors such as estrogen receptor (ER) and progesterone receptor $(\mathrm{PR})$ in concert with the oncogene ErbB-2/human epidermal growth factor receptor 2 (HER2 ) are critical determinants of the four main molecular subtypes of BC. Tumors of luminal A and luminal B subtypes are hormone receptor-positive (ER and/or PR-positive) and represent around 70\% of all BCs [5]. Luminal A tumors are often low grade with slow tumor growth and have the best prognosis. Luminal B cancers generally grow slightly faster than luminal A cancers and have a slightly worse prognosis. Both luminal types are treated with endocrine therapy [5]. On the other hand, HER2-positive subtypes (around 15\% of BCs) overexpress HER2, tend to grow faster than luminal cancers and can have a worse prognosis. But, they are often successfully treated with HER2-targeted therapies [6]. Triple negative (also called basal-like) tumors are ER negative, PR negative, and HER-2 negative. Although the basal-like subtype is only found in about $15 \%$ of $\mathrm{BC}$ diagnoses, it has been shown to be aggressive, unresponsive to treatment and, ultimately, indicative of a poor prognosis [7-11]. These classical molecular biomarkers (i.e. ER, PR, and HER2) are generally complemented with traditional clinicopathological factors (including tumor grade, lymphnode metastases and p53 status) and conventionally used for patient prognosis and management [12]. Recently, with the introduction of high-throughput technologies, numerous multigene tests such as urokinase plasminogen activator (UPA)-PAI-1, Oncotype DX, MammaPrint, EndoPredict, Breast Cancer Index (BCI) and Prosigna (PAM50), may be performed in specific subgroups of $\mathrm{BC}$ patients to predict outcome and aid adjunct therapy decision-making [2]. Current prospective clinical trials are seeking evidence for their definitive role in BC. The advances in molecular biomarkers and the progress in treatment modalities have together contributed to improvements in overall survival of $\mathrm{BC}$ patients. However, in many cases tumors do not respond to the currently available treatments or relapse after initial response [13]. Therefore, new biomarkers are needed to quantify the residual risk of $\mathrm{BC}$ patients and to indicate the potential value of additional treatment strategies to eliminate these resistant tumors.

Recent major scientific advances have demonstrated the importance of the immune system in malignant diseases including BC. Both innate and adaptive immune cells actively prevent neoplastic development in a process called 'cancer immunosurveillance' [14-16]. However, due to their genetic instability, malignant cells can develop several mechanisms to evade immunosurveillance $[17,18]$. Therefore, strategies designed to harness the immune system are the focus of several recent promising therapeutic approaches for cancer patients $[19,20]$. Natural killer (NK) cells are lymphocytes of the innate immune system that play a critical role in host immune responses against tumor growth and metastasis [21-23]. Following the progress in NK cell biology field and in understanding NK function, these lymphocytes have recently become a powerful cancer immunotherapy tool that presents several advantages [24]. Furthermore, a significant piece of experimental and clinical evidence supports the role of NK cells in BC control [22, 25-33], suggesting that NK cell-based therapy may become a potent strategy for the eradication of residual $\mathrm{BC}$ cells, prevention of relapse and improvement of patient survival.

NK cells recognize their target through a complex array of regulatory receptors that monitor cell surfaces of autologous or host cells for an aberrant expression of major histocompatibility complex (MHC) class I molecules and cell stress markers, which frequently occur in cancer cells $[34,35]$. In fact, upon cellular transformation, MHC class I expression on the cell surface is often reduced or lost to evade recognition by antitumor T cells. When NK cells encounter transformed cells lacking MHC class I, their inhibitory receptors are not engaged, and the unsuppressed activating signals, in turn, can trigger cytokine secretion and targeted attack of the transformed cells [36, 37]. In parallel, cellular stress and DNA damage (occurring in malignant transformation) result in upregulation of "stress ligands" that can be recognized by activating NK receptors [38]. Thus, human tumor cells that have lost self-MHC class I expression or bear "altered-self" stressinducible proteins are ideal targets for NK recognition and cytotoxicity [36, 39, 40]. However, during cancer progression, tumor cells deregulate the expression of these ligands by several mechanisms in order to escape from NK detection and elimination [41-48]. Thus, analysis of the expression of NK receptor ligands in BCs may allow the determination of new biomarkers to quantify the residual risk of patients and to indicate the potential value of additional NK-based treatment strategies.

The "Kaplan-Meier plotter" (KM plotter) is an online platform (http://kmplot.com/analysis/) that can be used to assess the effect of 54,675 genes on patient survival using 10,461 cancer samples (including breast, ovarian, lung and gastric cancers). This platform is established by using gene expression data and patient survival information downloaded from Gene Expression 
Omnibus (GEO) (Affymetrix microarrays only), European Genome-phenome Archive (EGA), and The Cancer Genome Atlas (TCGA). The database is handled by a PostgreSQL server, which integrates gene expression and clinical data simultaneously. The KM plotter was validated and widely used in many studies to identify a number of genes, as prognostic markers or potential drug targets in BC [49-54], lung cancer [51, 55-57], ovarian cancer [58$60]$ and gastric cancer [51, 61-63].

The aim of the present study was to determine the prognostic roles of mRNA expression of NK receptor ligands in $\mathrm{BC}$ patients and their association with different $\mathrm{BC}$ molecular subtypes and clinicopathological features. Therefore, we performed systematic literature screening to select and ascertain all NK-regulatory ligands for NK receptors identified to date. Then, we utilized to $\mathrm{KM}$ plotter to analyze their effect on BC patient relapse-free and overall survivals.

\section{RESULTS}

\section{Prognostic values of the mRNA expression of NK receptor ligands in $\mathrm{BC}$ patients}

First, we systematically screened the literature to identify ligands for NK receptors that regulate NK activity and cytotoxicity towards the target cells that express these ligands. In total, we selected 39 NK-regulatory ligands for NK receptors [64-133] (Table 1). Among these, 27 ligands for $17 \mathrm{NK}$ receptors that induce the cytotoxic activity of NK cells towards the target cells (NK-activating ligands), 8 ligands for $8 \mathrm{NK}$ receptors whose interaction inhibits the NK activity (NK-inhibitory ligands) and 4 ligands that can bind different NK receptors to either activate or inhibit NK activity (NK-activating and inhibitory ligands).

Next, we used the KM plotter platform to determine the influence of the mRNA expression level of 32 ligands from the identified genes (Table 1) on the survival of BC patients. The other 7 ligands (Table 1, Probe ID = N/A) could not be analyzed because they were not available on the KM plotter (viral genes, Fc $\gamma$ fragment of IgG, heparan sulfate and three other genes that had no related probe set). The analysis results of the correlation between mRNA expression of the $21 \mathrm{NK}$-activating ligands for NK receptors and survival are presented in Figure 1A (Red) for RFS and Figure 1B (Red) for OS. Patients with high mRNA expression of the NK-activating ligands B7-1 $(\mathrm{HR}=0.77,95 \% \mathrm{CI}=0.65-0.92, p=0.0053), \mathrm{B} 7-2(\mathrm{HR}$ $=0.86,95 \% \mathrm{CI}=0.77-0.96, p=0.0081), \mathrm{CD} 27(\mathrm{HR}=$ $0.66,95 \% \mathrm{CI}=0.59-0.73, p=0.00000000000033), \mathrm{CD} 48$ $(\mathrm{HR}=0.72,95 \% \mathrm{CI}=0.65-0.8, p=0.0000000071)$, $\mathrm{CD} 70(\mathrm{HR}=0.84,95 \% \mathrm{CI}=0.75-0.94, p=0.0027)$, $\mathrm{KMT} 2 \mathrm{E}(\mathrm{HR}=0.53,95 \% \mathrm{CI}=0.45-0.61, p=$ $0.0000000000000011)$, $\mathrm{MICA}(\mathrm{HR}=0.87,95 \% \mathrm{CI}=$ $0.78-0.97, p=0.013), \mathrm{MICB}(\mathrm{HR}=0.7,95 \% \mathrm{CI}=0.62$ $0.78, p=0.00000000032), \mathrm{NECL} 2(\mathrm{HR}=0.86,95 \% \mathrm{CI}=$
$0.76-0.96, p=0.0089), \mathrm{SLAMF} 6(\mathrm{HR}=0.56,95 \% \mathrm{CI}=$ $0.47-0.66, p=0.0000000000064), \mathrm{SLAMF} 7(\mathrm{HR}=0.66$, $95 \% \mathrm{CI}=0.55-0.81, p=0.000067), \mathrm{TNFSF} 9(\mathrm{HR}=0.69$, $95 \% \mathrm{CI}=0.61-0.77, p=0.00000000029), \mathrm{ULBP} 1(\mathrm{HR}$ $=0.71,95 \% \mathrm{CI}=0.63-0.79, p=0.0000000015), \mathrm{ULBP} 3$ $(\mathrm{HR}=0.81,95 \% \mathrm{CI}=0.68-0.96, p=0.015), \mathrm{ULBP} 4(\mathrm{HR}$ $=0.83,95 \% \mathrm{CI}=0.7-0.98, p=0.032)$ and VIM $(\mathrm{HR}=$ $0.86,95 \% \mathrm{CI}=0.76-0.97, p=0.012$ ) had significantly longer RFS than patients with lower mRNA expression of these ligands (Figure 1A, Red). The longer RFS in the patients expressing high levels of the above-mentioned 16 NK-activating ligands significantly was associated with longer OS for only 7 ligands; CD27, CD48, KMT2E, NECL2, SLAMF6, SLAMF7 and VIM (Figure 1B, Red). However, despite the longer RFS, MICA (HR $=1.27,95 \%$ $\mathrm{CI}=1.02-1.58, p=0.048)$ and ULBP3 $(\mathrm{HR}=1.66,95 \%$ $\mathrm{CI}=1.19-2.31, p=0.0075)$ were associated with shorter OS, while B7-1, B7-2, CD70, MICB, TNFS9, ULBP1 and ULBP4 didn't significantly correlate with OS (Figure 1B, Red).

On the other hand, patients with high mRNA expression of the NK-activating ligand ULBP2 had significantly worse $\mathrm{OS}(\mathrm{HR}=1.67,95 \% \mathrm{CI}=1.21-2.31$, $p=0.0054)$ and RFS (HR $=1.52,95 \% \mathrm{CI}=1.3-1.79$, $p=0.00000044)$. In addition, patients with high mRNA expression of the NK-activating ligands BAT3 $(\mathrm{HR}=1.17$, $95 \% \mathrm{CI}=1.04-1.29, p=0.01)$, AICL $(\mathrm{HR}=1.18,95 \% \mathrm{CI}$ $=1.05-1.32, p=0.0057)$ and $\mathrm{CD} 58(\mathrm{HR}=1.23,95 \% \mathrm{CI}=$ $1.1-1.39, p=0.00073$ ) had shorter RFS but not OS. CD72 didn't show any significant effect on OS or RFS.

The correlation between mRNA expression of 7 NK-inhibitory ligands for NK receptors and survival (RFS and OS) in BC patients was also analyzed (Figure $1 \mathrm{~A}$ and $1 \mathrm{~B}, \mathrm{Blue})$. Except for COL3A1 (HR = 1.16, $95 \% \mathrm{CI}=1.04-1.21, p=0.01)$ that associated with shorter RFS, patients with high mRNA expression of CEACAM1 $(\mathrm{HR}=0.79,95 \% \mathrm{CI}=0.7-0.88, p=$ $0.000046)$, CLEC2D $(\mathrm{HR}=0.5,95 \% \mathrm{CI}=0.42-0.58$, $p<0.000000000000001)$, HLA-A $(\mathrm{HR}=0.74,95 \% \mathrm{CI}=$ $0.66-0.82, p=0.00000012), \mathrm{HLA}-\mathrm{B}(\mathrm{HR}=0.69,95 \% \mathrm{CI}$ $=0.62-0.77, p=0.0000000001), \operatorname{PDL} 1(\mathrm{HR}=0.58,95 \%$ $\mathrm{CI}=0.5-0.68, p=0.000000000045)$ and PDL2 (HR $=$ $0.78,95 \% \mathrm{CI}=0.7-0.88, p=0.000054)$ had significantly higher RFS than do patients with lower mRNA expression of these ligands (Figure 1A, Blue), which also associated with longer OS for CLEC2D, HLA-A, HLA-B and PDL1 (Figure 1B, Blue).

The four ligands that can bind activating and inhibitory NK receptors; HLA-C, HLA-E, NECL5 and NECTIN2 all associate with better RFS and OS, except for NECL5 that only significantly associated with better RFS (Figure 1A and 1B, Green).

Taken together, these results indicate that the high mRNA expression of most (around 80\%) ligands for NK activating and inhibitory receptors associate with better RFS in BC patients. However, while the longer 
Table 1: Activating and Inhibitory ligands for NK receptors

\begin{tabular}{|c|c|c|c|}
\hline Ligand & Corresponding NK receptor(s) & References & Probe ID \\
\hline \multicolumn{4}{|l|}{ NK-activating ligands } \\
\hline AICL & NKp80 & {$[76]$} & 209732_at \\
\hline B7-1, CD80 & Unknown & {$[68,71,77]$} & 1554519_at \\
\hline B7-2, CD86 & Unknown & {$[71,77]$} & 205685_at \\
\hline B7-H6 & NCR3, NKp30 & {$[66]$} & N/A \\
\hline BAT3 & NCR3, NKp30 & {$[73]$} & 210208_x_at \\
\hline $\mathrm{CD} 27$ & CD70 & {$[64]$} & 206150_at \\
\hline CD48 & 2B4, CD244 & {$[67,69,70]$} & 204118_at \\
\hline CD58 & $\mathrm{CD} 2$ & {$[132,133]$} & 205173_x_at \\
\hline CD70 & CD27 & {$[74]$} & 206508_at \\
\hline CD72 & CD100 & {$[72]$} & 215925_s_at \\
\hline Fc $\gamma$ fragment of IgG & Fc $\gamma$ receptor III, CD16 & {$[75]$} & $\mathrm{N} / \mathrm{A}$ \\
\hline Heparan sulfate & $\begin{array}{l}\text { 1. NCR1, NKp46 } \\
\text { 2. NCR2, NKp44 } \\
\text { 3. NCR3, NKp30 }\end{array}$ & $\begin{array}{l}\text { 1. }[65,88] \\
\text { 2. }[88] \\
\text { 3. }[65,88]\end{array}$ & $\mathrm{N} / \mathrm{A}$ \\
\hline KMT2E, NKp44L & NCR2, NKp44 & {$[80]$} & 226100_at \\
\hline MICA & NKG2D & [79] & 205904_at \\
\hline $\mathrm{MICB}$ & NKG2D & {$[79,83]$} & 206247_at \\
\hline NECL2 & CRTAM & [81] & 209031_at \\
\hline SLAMF6, NTB-A & SLAMF6, NTB-A & {$[85]$} & 1552497_a_at \\
\hline SLAMF7, CS1 & SLAMF7, CS1 & [91] & 222838_at \\
\hline TNFSF9, 4-1BBL, CD137L & TNFRSF9, 4-1BB, CD137 & {$[86,89,90,93]$} & 206907_at \\
\hline ULBP1 & NKG2D & {$[83]$} & 221323_at \\
\hline ULBP2 & NKG2D & {$[83]$} & 238542_at \\
\hline ULBP3 & NKG2D & {$[83]$} & 231748_at \\
\hline ULBP4 & NKG2D & {$[78,82]$} & 1552777_a_at \\
\hline ULBP5 & NKG2D & {$[78]$} & $\mathrm{N} / \mathrm{A}$ \\
\hline ULBP6 & NKG2D & {$[84]$} & $\mathrm{N} / \mathrm{A}$ \\
\hline VIM & NCR1, NKp46 & {$[87]$} & 201426_s_at \\
\hline Viral HA, HN & $\begin{array}{l}\text { 1. NCR1, NKp46 } \\
\text { 2. NCR2, NKp44 }\end{array}$ & $\begin{array}{l}\text { 1. }[92] \\
\text { 2. }[94]\end{array}$ & $\mathrm{N} / \mathrm{A}$ \\
\hline \multicolumn{4}{|c|}{ NK-activating and inhibitory ligands } \\
\hline HLA-C & $\begin{array}{l}\text { 1. CD160 (activating) } \\
\text { 2. KIR2DS1, p50.1 (activating) } \\
\text { 3. KIR2DS4, NKAT8 (activating) } \\
\text { 4. KIR2DL1, p58.1 (inhibitory) } \\
\text { 5. KIR2DL2, p58.2 (inhibitory) } \\
\text { 6. KIR2DL3, p58 (inhibitory) }\end{array}$ & $\begin{array}{c}1 .[104] \\
\text { 2. }[95,107] \\
\text { 3. }[97,103] \\
\text { 4.5.6. }[100,108,109]\end{array}$ & 216526_x_at \\
\hline HLA-E & $\begin{array}{l}\text { 1. NKG2A (inhibitory) } \\
\text { 2. NKG2B (inhibitory) } \\
\text { 3. NKG2C (activating) } \\
\text { 4. NKG2E (activating) }\end{array}$ & $\begin{array}{c}\text { 1. }[96,98,101,102,105,106] \\
\text { 2. }[96,98] \\
\text { 3. }[96,101,102] \\
\text { 4. }[102]\end{array}$ & 200904_at \\
\hline NECL5, PVR & $\begin{array}{l}\text { 1. CD96 (activating) } \\
\text { 2. CD226, DNAM1 (activating) } \\
\text { 3. TIGIT (inhibitory) }\end{array}$ & $\begin{array}{l}\text { 1. }[99,115,123] \\
\text { 2. }[112] \\
\text { 3. }[124]\end{array}$ & 214443_at \\
\hline
\end{tabular}




\begin{tabular}{|c|c|c|c|}
\hline NECTIN2, CD112, PVRL2 & $\begin{array}{l}\text { 1. CD226, DNAM1 (activating) } \\
\text { 2. PVRIG, CD112R (inhibitory) } \\
\text { 3. TIGIT (inhibitory) } \\
\end{array}$ & $\begin{array}{l}\text { 1. }[112] \\
\text { 2. }[125] \\
\text { 3. }[124,125] \\
\end{array}$ & 203149_at \\
\hline \multicolumn{4}{|l|}{ NK-inhibitory ligands } \\
\hline CEACAM1 & CEACAM1 & {$[118,119]$} & 209498_at \\
\hline CLEC2D, LLT1 & CD161, NKRP1A & {$[110,122]$} & 235522_at \\
\hline COL3A1 & LAIR1, CD305 & {$[117,120]$} & 211161_s_at \\
\hline hCMV PP65 & NCR3, NKp30 & [111] & N/A \\
\hline HLA-A & $\begin{array}{l}\text { 1. KIR3DL2, p140 } \\
\text { 2. LILRB1, ILT2 }\end{array}$ & $\begin{array}{c}\text { 1. }[114,116,121,126] \\
\text { 2. }[113]\end{array}$ & 215313_x_at \\
\hline HLA-B & $\begin{array}{l}\text { 1. KIR3DL1, NKB1 } \\
\text { 2. LILRB1, ILT2 }\end{array}$ & $\begin{array}{l}\text { 1. }[128] \\
\text { 2. }[113]\end{array}$ & 209140_x_at \\
\hline PDL1 & PD-1 & {$[127,130]$} & 227458_at \\
\hline PDL2 & PD-1 & {$[127,129]$} & $220049 \mathrm{~s}$ at \\
\hline
\end{tabular}

Abbreviations: AICL, activation-induced C-type lectin; B7-1/2, B-lymphocyte activation antigen B7-1/2; B7-H6, B7 homolog 6; BAT3, HLA-B-associated transcript 3; CD, cluster of differentiation; CEACAM1, carcinoembryonic antigenrelated cell adhesion molecule 1; CLEC2D, C-type lectin domain family 2 member D; COL3A1, collagen type 3 alpha 1; CRTAM, class I-restricted T-cell-associated molecule; CS1, CD2 subset 1; DNAM1, DNAX accessory molecule-1; HA, haemagglutinin; hCMV PP65, human cytomegalovirus pp65; HLA-A/B/C/E, human leukocyte antigen-A/B/C/E; $\mathrm{HN}$, haemagglutinin neuramidase; ILT2, Ig-like transcript 2; KIRxDLy, killer cell immunoglobulin like receptor "x" Ig domains and long cytoplasmic tail "y"; KLRG1, killer cell lectin like receptor G1; KMT2E, lysine methyltransferase 2E; LAIR1, leukocyte associated immunoglobulin like receptor 1; LILRB1, leukocyte immunoglobulin like receptor B1; LLT1, Lectin-Like Transcript-1; MICA/B, MHC class I polypeptide-related sequence A/B; NCR1/2/3, natural cytotoxicity triggering receptor $1 / 2 / 3$; NECL2/5, nectin-like protein $2 / 5$; NECTIN2, nectin cell adhesion molecule 2; NKG2A/B/C/D/E, natural-killer group 2 member A/B/C/D/E; NKRP1A, NK receptor-P1A; NTB-A, NK-, T-, and B-cell antigen; N/A, not available; PD-1/2, programmed death receptor-1/2; PDL1, programmed death ligand 1; PVR, poliovirus receptor; PVRIG, PVR related immunoglobulin domain containing); PVRL2, poliovirus receptor related 2; SLAMF6/7, signaling lymphocytic activation molecule family member 6/7; TIGIT, T-cell immunoreceptor with Ig and ITIM domains; TNFSF9, tumor necrosis factor superfamily member 9; ULBP1-6, UL16 binding protein 1-6; VIM, vimentin.

RFS correlates with longer OS for most NK-inhibitory ligands, in only about half of the NK-activating ligands it significantly correlates with longer OS. On the other hand, six NK-activating ligands (AICL, BAT3, CD58, MICA, ULBP2 and ULBP3) correlated with worse prognosis (shorter RFS and/or OS) in BC patients (Figure 1C).

\section{Association between the prognostic role of the mRNA expression of NK receptor ligands and the $\mathrm{BC}$ subtypes}

In $\mathrm{BC}$, the treatment selection and clinical outcome are mainly defined by molecular subtypes. Therefore, we next checked whether the prognostic influence of NK receptor ligands might be dependent on any specific BC subtype(s) (luminal A, luminal B, HER2-type and/or basal-like) (Table 2 and Figure 2).

Among the NK-activating ligands that were associated with longer RFS in all BC patients (Figure 1), the prognostic values of only CD27, MICB, SLAMF6, TNFSF9, and ULBP1 were found to be independent of the $\mathrm{BC}$ subtype as their high expression was associated with longer RFS in all BC subtypes (Table 2). Other ligands were associated with longer RFS in all subtypes but one; luminal A subtype for B7-1, B7-2, CD48, CD72, and SLAMF7 or basal-like subtype for KMT2E (Table 2). However, the prognostic value of the other NK-activating ligands was subtype specific. Particularly, ULBP4 associated with longer RFS specifically in luminal B and basal-like subtypes, CD70 associated with longer RFS specifically in luminal B and HER2-positive subtypes while the favorable prognostic significance of VIM was specifically dependent on luminal A and B subtypes (Table 2). On the other hand, AICL and ULBP2 were associated with shorter RFS specifically in luminal A/B and basal-like subtypes, respectively (Table 2). Contrarily, NECL2, MICA, and BAT3 had opposing prognostic significance depending on the BC subtype (Table 2).

Among the NK-activating ligands that were associated with longer $\mathrm{OS}$ in all $\mathrm{BC}$ patients, the prognostic values of only CD48 and CD27 were found to be independent of the $\mathrm{BC}$ subtype as their expression was associated with longer OS in all BC subtypes (Table 2). Furthermore, SLAMF7 and VIM were associated with longer OS in HER2-positive/basal-like subtypes and luminal A/HER2-positive subtypes, respectively (Table 2). Contrarily, ULBP2 was associated with worse prognosis specifically in basal-like subtype (Table 2). 
A

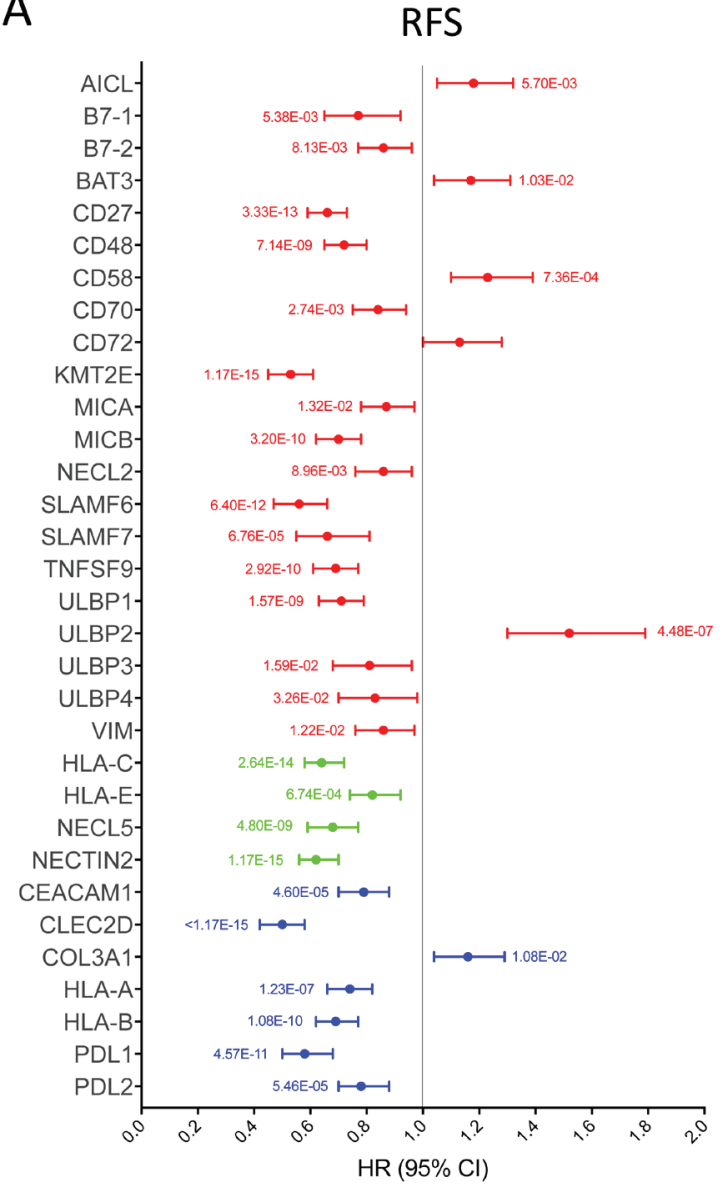

C
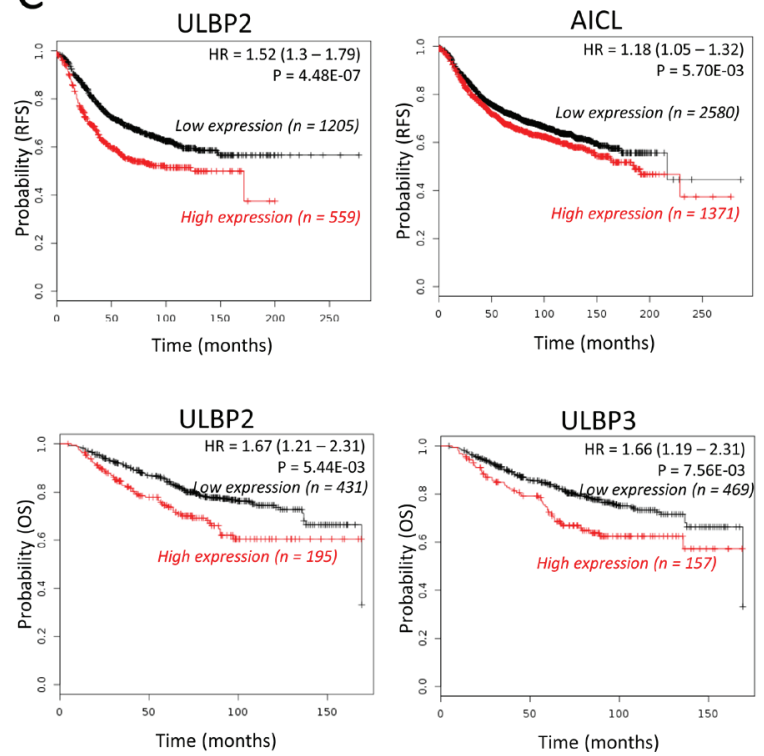

B

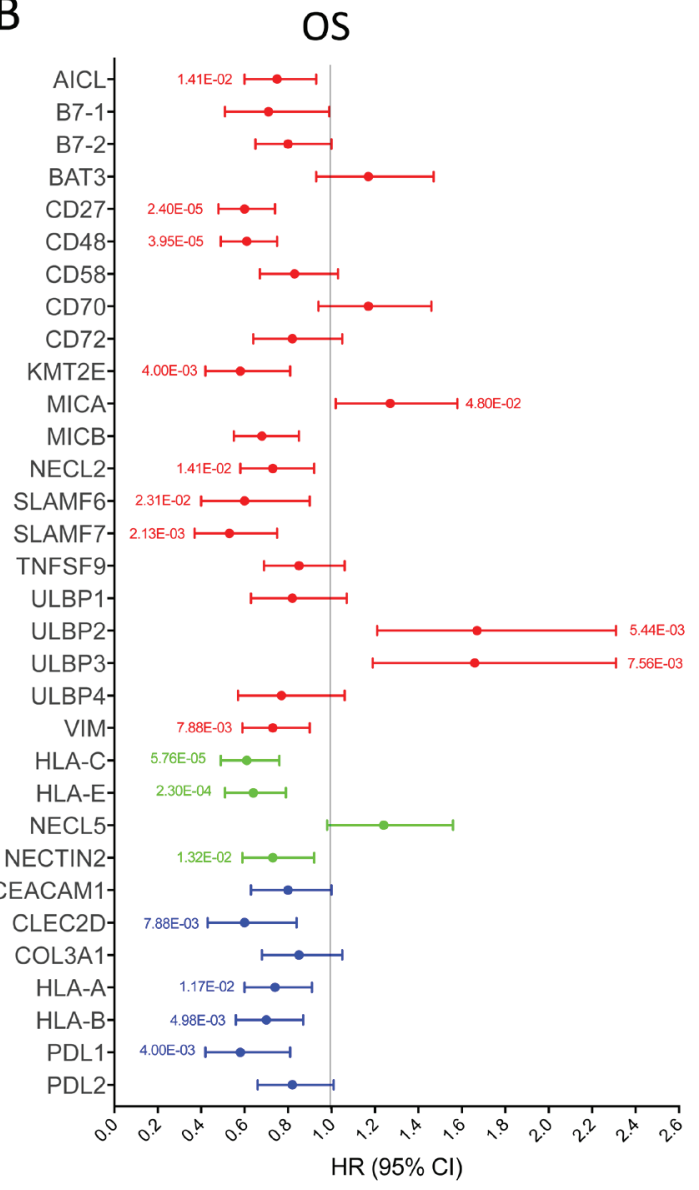

BAT3
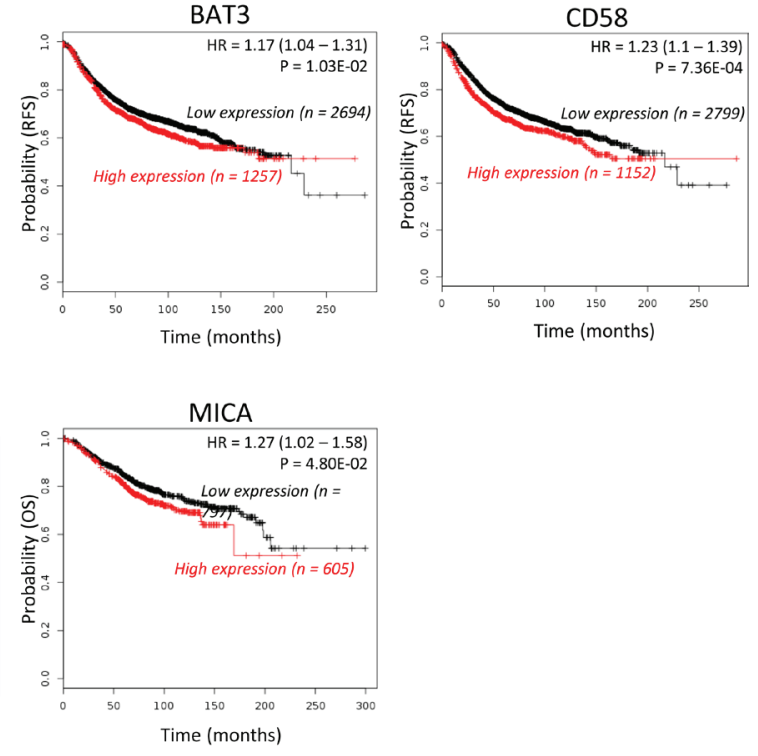

Figure 1: Prognostic values of the mRNA expression of NK receptor ligands in all breast cancer patients. The correlation of the individual expression of 32 NK receptor ligands' mRNA to RFS (A) and OS (B) was analyzed, in 3951 and 1402 breast cancer patients, respectively, on the KM plotter database. For each ligand, the bar represents the HR (95\% CI). The $p$ value is indicated next to each bar when the data is statistically significant ( $p$ value $<0.05$ ). The bar color (red, blue or green) represents the effect of the ligand on NK activity (activation, inhibition or both depending on the receptor type, respectively). The line at HR = 1 separates the ligands according to the prognostic influence of their high mRNA expression; better survival (HR $<1)$ and worse survival $(\mathrm{HR}>1)$. (C) Kaplan-Meier survival plots of RFS (upper plots) and OS (lower plots) durations in BC patients with the expression levels of the NK-activating ligands that specifically correlated with poor prognosis. The " $n$ " values represent the number of BC patients in each cohort. 
Table 2: Association between the prognostic role of mRNA expression of NK receptor ligands and BC subtypes

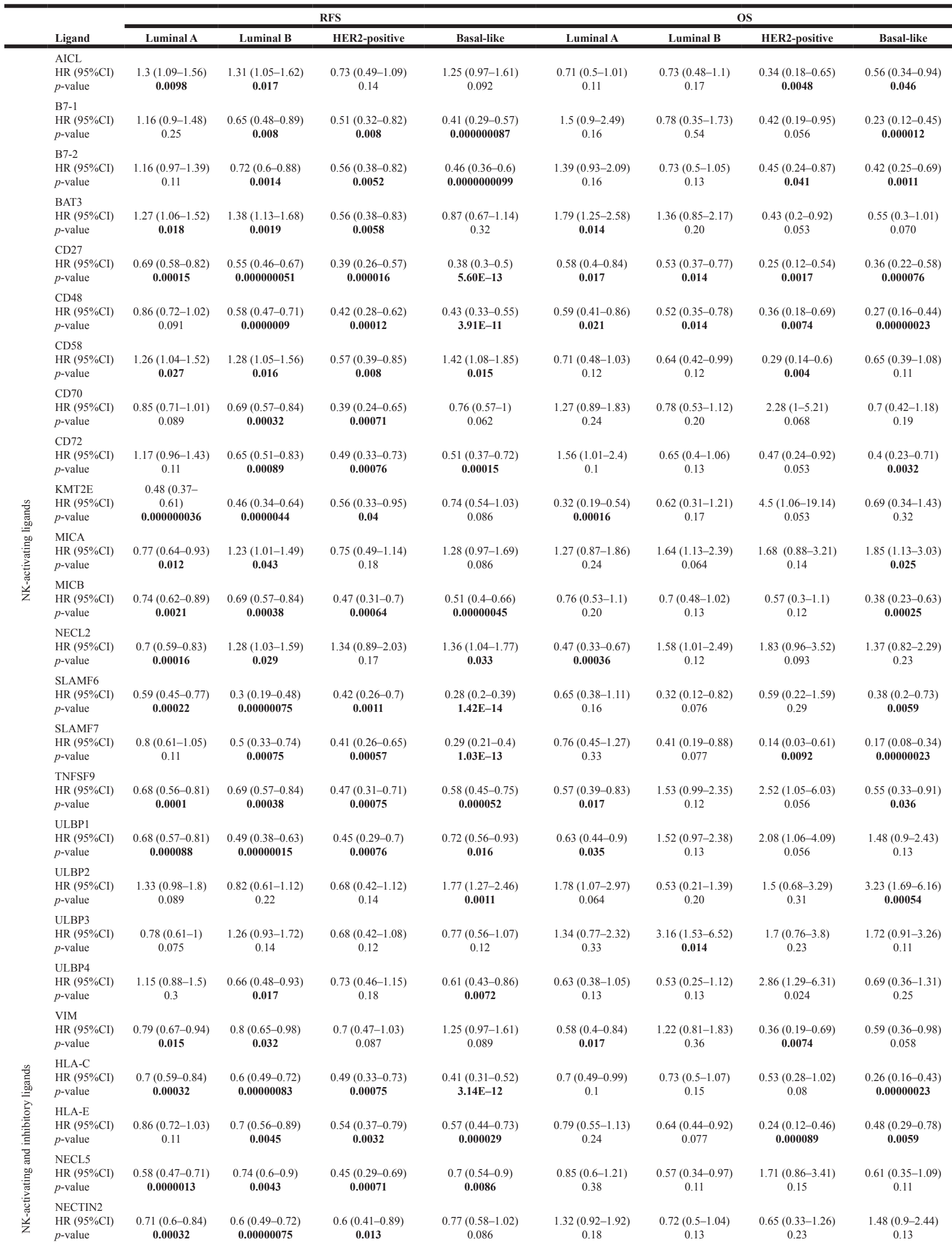




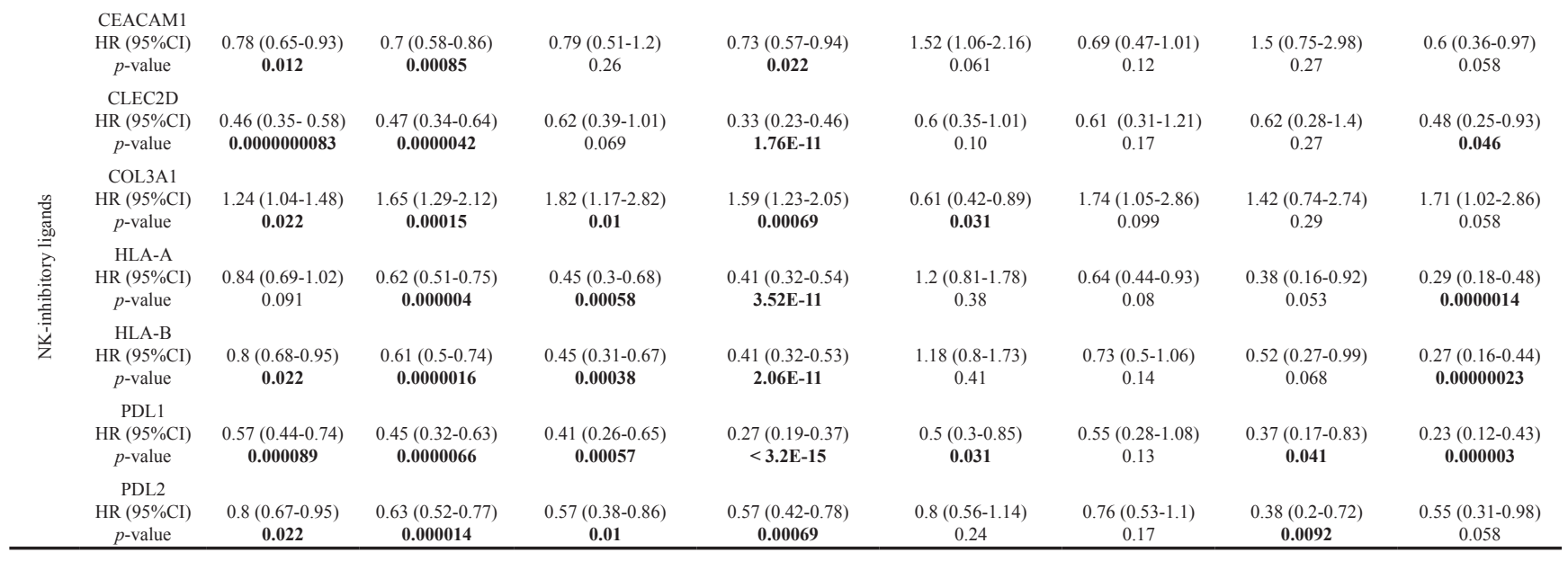

Taking into account all 21 NK-activating ligands as a whole (Figure 2), we observed that 43\%, 66.5\%, 66.5\% and $52.4 \%$ of these ligands correlated with longer RFS in $\mathrm{BC}$ patients with tumors of luminal A, luminal B, HER2positive and basal-like subtypes, respectively (Figure $2 \mathrm{~A}$, left graph). When analyzing the percentage of NKactivating ligands whose high expression was associated with longer OS, it dropped to $33.3 \%, 9.6 \%, 33.3 \%$ and $47.7 \%$, respectively (Figure 3A, right graph). The degree of the loss of the favorable prognostic influence of NKactivating ligands, on OS relative to RFS, varied depending on the BC subtype: slight drop for basal-like subtype (9\%), moderate drop for luminal A and HER2-positive subtypes (22.5\% and 50\% respectively) and dramatic drop for luminal B subtype (85.5\% less NK-activating ligands associated with longer OS than with longer RFS) (Figure 2A). Interestingly, when comparing the effect of high mRNA expression of the NK-activating ligands on OS, the HR values appeared to be lower in the basal-like and HER2-positive subtypes in comparison to those of luminal $\mathrm{A}$ and $\mathrm{B}$ subtypes. In fact, the median HR values were $0.55,0.57,0.74$, and 0.73 for basal-like, HER2-positive, luminal A and luminal B, respectively (Figure 2B). In other word, patients with HER2-positive or basal-like tumors expressing high mRNA levels of NK-activating ligands were $42-45 \%$ less likely to die than patients with low expression levels of these ligands, whereas patients with luminal A/B tumors were $26-27 \%$ less likely to die. Thus, high mRNA expression of NK-activating ligands, as a whole, is associated with $16-18 \%$ more chance of survival in patients with HER2-positive or basal-like BC than in patients with luminal A or luminal B BC.

On the other hand, except for COL3A1 that correlated with worse RFS in all BC subtypes, all the ligands that bind NK-inhibitory receptors were associated with better RFS mainly in a subtype-independent manner (Table 2). However, the association between these ligands and OS is more variable and subtype-dependent (Table 2).

Taken together, these results indicate that NK receptor ligands, whether activating or inhibitory, are mainly associated with favorable RFS. When taken individually, the prognostic value of some NK receptor ligands is independent of $\mathrm{BC}$ subtypes while for others it is more subtype-specific. Interestingly, the favorable prognostic influence of NK-activating ligands' upregulation, as a whole, is higher in HER2-positive and basal-like $\mathrm{BC}$ subtypes.

\section{Association between the prognostic role of the mRNA expression of NK receptor ligands and the lymph node status of $\mathrm{BC}$ patients}

The most significant prognostic indicator for patients with early-stage $\mathrm{BC}$ is the presence (lymph node positive) or absence (lymph node negative) of axillary lymph node involvement [134]. Therefore, we next checked whether the prognostic influence of NK receptor ligands might be dependent on the lymph node status in $\mathrm{BC}$ patients (Table 3 and Figure 3).

Among all 21 NK-activating ligands, only CD27 was associated with longer RFS in both lymph node negative and positive $\mathrm{BC}$ patients (Table 3 ) while three ligands (AICL, MICB and SLAMF6) were associated with longer RFS specifically in lymph node positive BC patients but not in lymph node negative patients (Table 3). However, none of the NK-activating ligands specifically associated with better RFS in only lymph node negative $\mathrm{BC}$ patients (Table 3 ). On the other hand, three ligands: BAT3 (only in lymph node negative BCs), CD70 (only in lymph node positive BCs) and ULBP2 (in both lymph node negative and positive $\mathrm{BCs}$ ) correlated with shorter RFS (Table 3). The prognostic significance observed for RFS correlated with OS for AICL, CD27, CD70, and MICB ligands but not for SLAMF6, ULBP2, and BAT3 ligands (Table 3 ).

Regarding the NK-inhibitory ligands, HLA-B and PDL1 on the one hand and CLEC2D, COL3A1 and HLA-A on the other hand were associated with longer RFS specifically in lymph node negative and lymph node positive BCs, respectively (Table 3 ). Among these, the association with RFS of only HLA-B correlated with OS (Table 3). 
Regarding the ligands that can bind both NKactivating and inhibitory receptors, they all significantly associated with longer RFS in lymph node negative BCs but this was also true in lymph node positive BCs for only NECTIN2 (Table 3). The association between the mRNA expression of these ligands and OS was more variable depending on the lymph node status (Table 3 ).
Overall, although the median HR values for all NK-activating ligands were similar between lymph node positive and lymph node negative BCs for both RFS and OS (Figure 3B), more NK activating ligands were associated with better prognosis in lymph node positive BC patients $(4-8 / 21,19-38 \%)$ than in lymph node negative BC patients (1-6/21, 4.7-28.1\%), for RFS-OS,
A

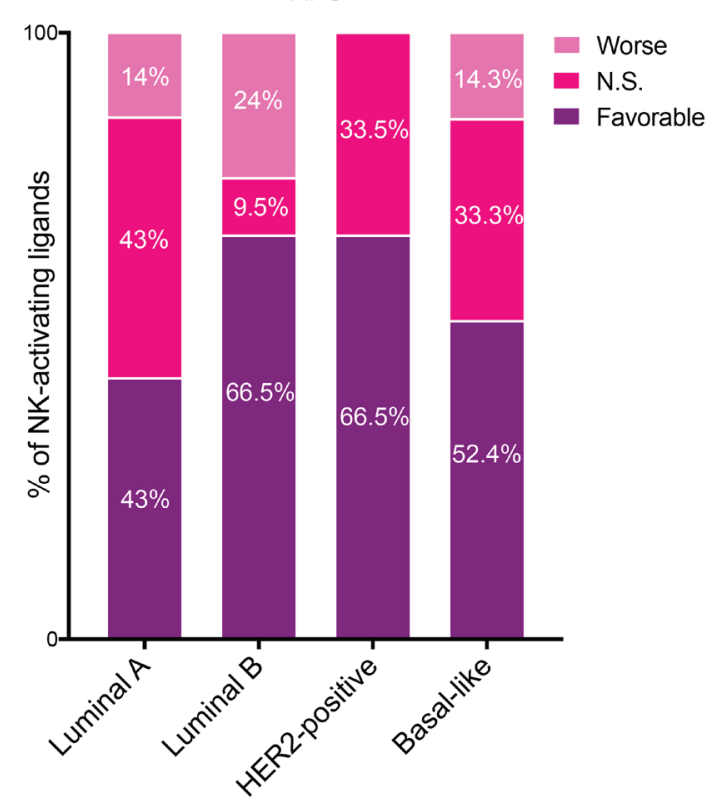

RFS

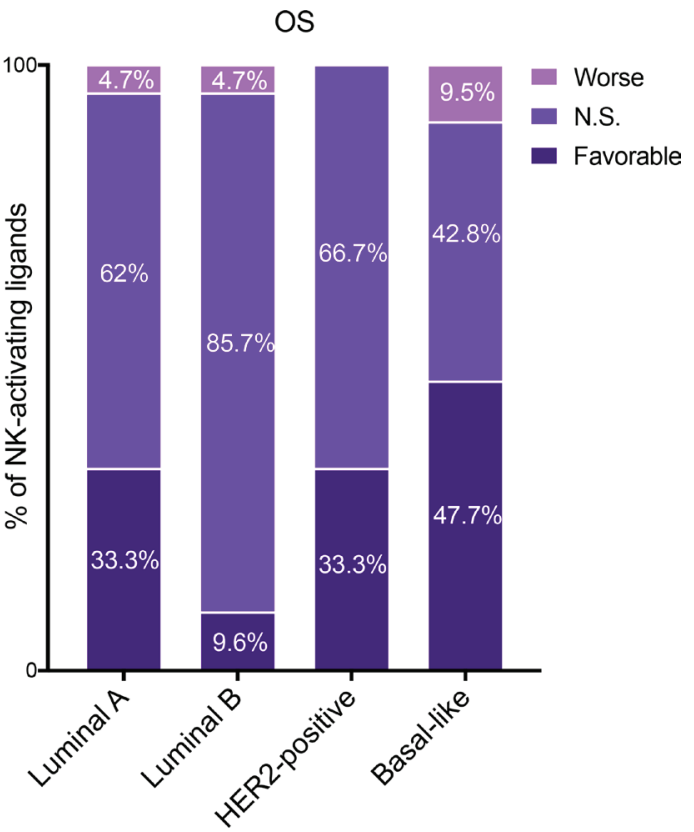

B
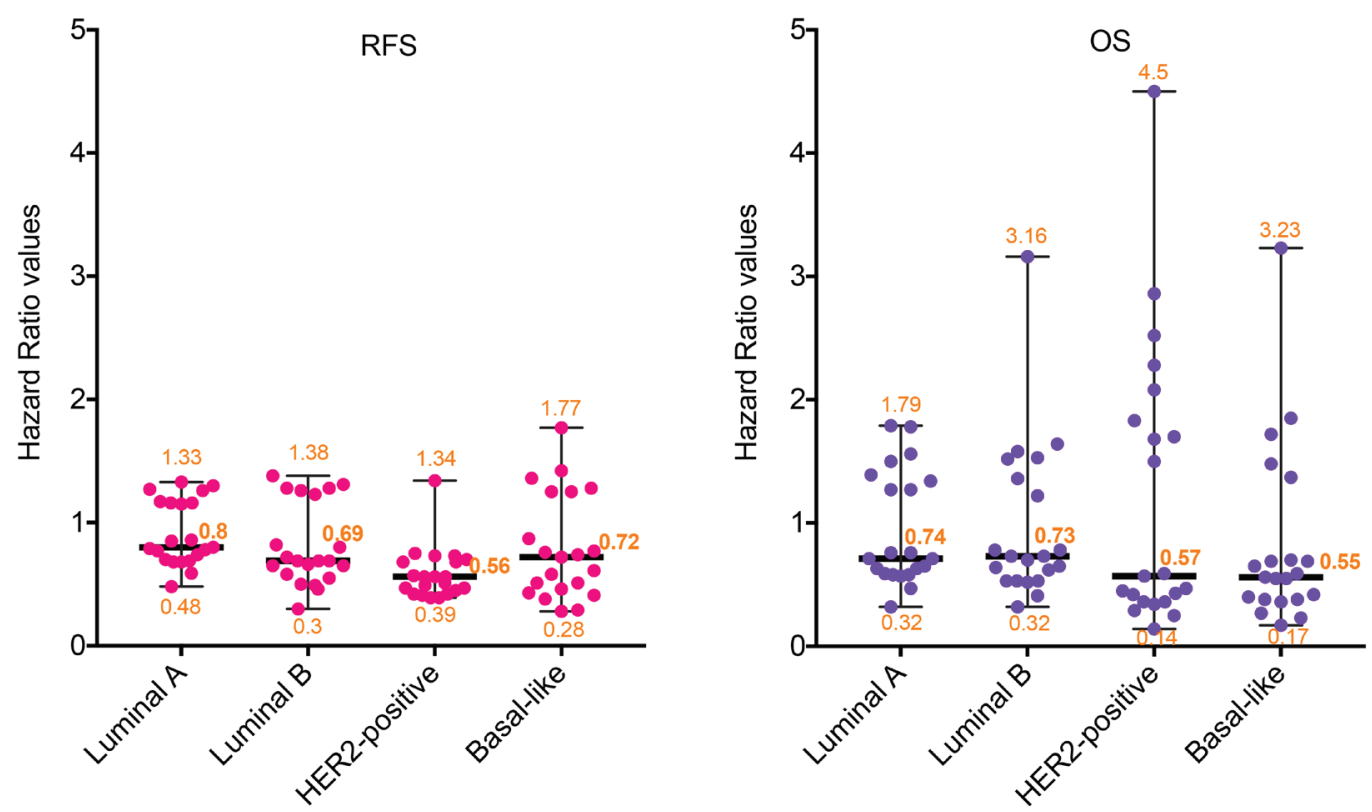

Figure 2: Prognostic values of the mRNA expression of NK-activating ligands depending on the BC molecular subtype. (A) Percentages of the NK-activating ligands whose high mRNA expression significantly associated (Favorable and Worse) or not (N.S.) with RFS (Left graph) or OS (Right graph) in the different BC subtypes. "Favorable" indicates the association of high mRNA expression with longer RFS/OS, representing good prognosis. "Worse" indicates the association of the high mRNA expression with shorter RFS/ OS, representing bad prognosis. "N.S." indicates no significant association with prognosis. (B) Individual value plots visualizing the distribution of the hazard ratio (HR) values of the NK-activating ligands in the different BC subtypes. The bars represent the median, lower and higher HR values for all ligands in each subtype. 
Table 3: Association between the prognostic role of mRNA expression of NK receptor ligands and lymph-node status

\begin{tabular}{|c|c|c|c|c|c|}
\hline \multirow{2}{*}{ Ligand } & & \multicolumn{2}{|c|}{ RFS } & \multicolumn{2}{|c|}{ OS } \\
\hline & Ligand & Lymph node negative & Lymph node positive & Lymph node negative & $\begin{array}{l}\text { Lymph node } \\
\text { positive }\end{array}$ \\
\hline \multirow{21}{*}{ 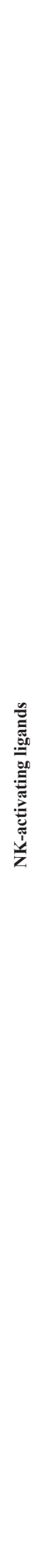 } & $\begin{array}{c}\text { AICL } \\
\text { HR ( } 95 \% \mathrm{CI}) \\
p \text {-value }\end{array}$ & $\begin{array}{c}0.89(0.73-1.08) \\
0.24\end{array}$ & $\begin{array}{c}0.74(0.60-0.91) \\
\mathbf{0 . 0 2 8}\end{array}$ & $\begin{array}{c}1.52(1.05-2.20) \\
0.069\end{array}$ & $\begin{array}{c}0.44(0.30-0.66) \\
\mathbf{0 . 0 0 1 1}\end{array}$ \\
\hline & $\begin{array}{c}\text { B7-1 } \\
\text { HR (95\%CI) } \\
p \text {-value }\end{array}$ & $\begin{array}{c}1.36(0.89-2.07) \\
0.18\end{array}$ & $\begin{array}{c}0.71(0.52-0.96) \\
0.064\end{array}$ & $\begin{array}{c}0.40(0.15-1.04) \\
0.12\end{array}$ & $\begin{array}{c}0.48(0.28-0.84) \\
\mathbf{0 . 0 2 1}\end{array}$ \\
\hline & $\begin{array}{c}\text { B7-2 } \\
\text { HR (95\%CI) } \\
p \text {-value }\end{array}$ & $\begin{array}{c}1.16(0.96-1.40) \\
0.18\end{array}$ & $\begin{array}{c}1.19(0.97-1.44) \\
0.12\end{array}$ & $\begin{array}{c}0.78(0.54-1.13) \\
0.26\end{array}$ & $\begin{array}{c}0.83(0.55-1.24) \\
0.39\end{array}$ \\
\hline & $\begin{array}{c}\text { BAT3 } \\
\text { HR }(95 \% \text { CI) } \\
p \text {-value }\end{array}$ & $\begin{array}{c}1.44(1.21-1.70) \\
\mathbf{0 . 0 0 0 9 9}\end{array}$ & $\begin{array}{c}0.81(0.67-1.00) \\
0.081\end{array}$ & $\begin{array}{c}1.32(0.87-2.02) \\
0.26\end{array}$ & $\begin{array}{c}1.50(1.02-2.21) \\
0.073\end{array}$ \\
\hline & $\begin{array}{c}\text { CD27 } \\
\text { HR (95\%CI) } \\
p \text {-value }\end{array}$ & $\begin{array}{c}0.73(0.62-0.87) \\
\mathbf{0 . 0 0 1 8}\end{array}$ & $\begin{array}{c}0.7(0.57-0.85) \\
\mathbf{0 . 0 0 2 4}\end{array}$ & $\begin{array}{c}0.62(0.42-0.9) \\
\mathbf{0 . 0 4 5}\end{array}$ & $\begin{array}{c}0.46(0.31-0.68) \\
\mathbf{0 . 0 0 1 1}\end{array}$ \\
\hline & $\begin{array}{c}\text { CD48 } \\
\text { HR ( } 95 \% \mathrm{CI}) \\
p \text {-value }\end{array}$ & $\begin{array}{c}0.87(0.74-1.03) \\
0.18\end{array}$ & $\begin{array}{c}0.79(0.65-0.96) \\
0.058\end{array}$ & $\begin{array}{c}0.71(0.49-1.04) \\
0.16\end{array}$ & $\begin{array}{c}0.47(0.32-0.70) \\
\mathbf{0 . 0 0 1 1}\end{array}$ \\
\hline & $\begin{array}{c}\text { CD58 } \\
\text { HR (95\%CI) } \\
p \text {-value }\end{array}$ & $\begin{array}{c}0.79(0.64-0.96) \\
0.057\end{array}$ & $\begin{array}{c}1.2(1-1.44) \\
0.081\end{array}$ & $\begin{array}{c}0.58(0.39-0.86) \\
\mathbf{0 . 0 4 4}\end{array}$ & $\begin{array}{c}1.36(0.9-2.07) \\
0.18\end{array}$ \\
\hline & $\begin{array}{c}\text { CD70 } \\
\text { HR (95\%CI) } \\
p \text {-value }\end{array}$ & $\begin{array}{c}1.16(0.96-1.40) \\
0.18\end{array}$ & $\begin{array}{c}1.30(1.07-1.59) \\
\mathbf{0 . 0 3 2}\end{array}$ & $\begin{array}{c}1.25(0.86-1.81) \\
0.27\end{array}$ & $\begin{array}{c}1.66(1.10-2.49) \\
\mathbf{0 . 0 3 4}\end{array}$ \\
\hline & $\begin{array}{c}\text { CD72 } \\
\text { HR (95\%CI) } \\
p \text {-value }\end{array}$ & $\begin{array}{c}0.86(0.71-1.04) \\
0.18\end{array}$ & $\begin{array}{c}1.09(0.87-1.37) \\
0.47\end{array}$ & $\begin{array}{c}0.82(0.57-1.19) \\
0.30\end{array}$ & $\begin{array}{c}0.52(0.33-0.81) \\
\mathbf{0 . 0 1 2}\end{array}$ \\
\hline & $\begin{array}{c}\text { KMT2E } \\
\text { HR ( } 95 \% \mathrm{CI}) \\
p \text {-value }\end{array}$ & $\begin{array}{c}0.7(0.44-1.1) \\
0.18\end{array}$ & $\begin{array}{c}1.15(0.89-1.48) \\
0.30\end{array}$ & $\begin{array}{c}0.19(0.06-0.59) \\
\mathbf{0 . 0 4 3}\end{array}$ & $\begin{array}{c}1.28(0.76-2.16) \\
0.39\end{array}$ \\
\hline & $\begin{array}{c}\text { MICA } \\
\text { HR }(95 \% \mathrm{CI}) \\
p \text {-value }\end{array}$ & $\begin{array}{c}1.12(0.93-1.34) \\
0.24\end{array}$ & $\begin{array}{c}0.83(0.67-1.03) \\
0.12\end{array}$ & $\begin{array}{c}1.35(0.91-2.02) \\
0.24\end{array}$ & $\begin{array}{c}1.19(0.81-1.76) \\
0.39\end{array}$ \\
\hline & $\begin{array}{c}\text { MICB } \\
\text { HR }(95 \% \mathrm{CI}) \\
p \text {-value }\end{array}$ & $\begin{array}{c}0.88(0.74-1.06) \\
0.22\end{array}$ & $\begin{array}{c}0.66(0.54-0.81) \\
\mathbf{0 . 0 0 0 6 5}\end{array}$ & $\begin{array}{c}0.77(0.50-1.20) \\
0.27\end{array}$ & $\begin{array}{c}0.49(0.33-0.72) \\
\mathbf{0 . 0 0 1 8}\end{array}$ \\
\hline & $\begin{array}{c}\text { NECL2 } \\
\text { HR ( } 95 \% \text { CI) } \\
p \text {-value }\end{array}$ & $\begin{array}{c}0.85(0.72-1.01) \\
0.13\end{array}$ & $\begin{array}{c}0.81(0.66-1.00) \\
0.081\end{array}$ & $\begin{array}{c}0.57(0.40-0.83) \\
\mathbf{0 . 0 4 3}\end{array}$ & $\begin{array}{c}0.71(0.46-1.10) \\
0.16\end{array}$ \\
\hline & $\begin{array}{c}\text { SLAMF6 } \\
\text { HR ( } 95 \% \text { CI) } \\
p \text {-value }\end{array}$ & $\begin{array}{c}0.64(0.43-0.94) \\
0.057\end{array}$ & $\begin{array}{c}0.70(0.54-0.90) \\
\mathbf{0 . 0 2 8}\end{array}$ & $\begin{array}{c}1.72(0.68-4.37) \\
0.27\end{array}$ & $\begin{array}{c}0.80(0.46-1.39) \\
0.44\end{array}$ \\
\hline & $\begin{array}{c}\text { SLAMF7 } \\
\text { HR ( } 95 \% \mathrm{CI}) \\
p \text {-value }\end{array}$ & $\begin{array}{c}0.58(0.35-0.94) \\
0.057\end{array}$ & $\begin{array}{c}0.70(0.51-0.96) \\
0.066\end{array}$ & $\begin{array}{c}0.72(0.28-1.84) \\
0.49\end{array}$ & $\begin{array}{c}0.33(0.17-0.65) \\
\mathbf{0 . 0 0 4 5}\end{array}$ \\
\hline & $\begin{array}{c}\text { TNFSF9 } \\
\text { HR }(95 \% \text { CI) } \\
p \text {-value }\end{array}$ & $\begin{array}{c}0.85(0.72-1.01) \\
0.12\end{array}$ & $\begin{array}{c}1.09(0.90-1.33) \\
0.39\end{array}$ & $\begin{array}{c}0.57(0.39-0.84) \\
\mathbf{0 . 0 4 3}\end{array}$ & $\begin{array}{c}0.76(0.50-1.15) \\
0.22\end{array}$ \\
\hline & $\begin{array}{c}\text { ULBP1 } \\
\text { HR ( } 95 \% \text { CI) } \\
p \text {-value }\end{array}$ & $\begin{array}{c}0.85(0.71-1.03) \\
0.18\end{array}$ & $\begin{array}{c}1.22(0.97-1.55) \\
0.12\end{array}$ & $\begin{array}{c}0.62(0.42-0.91) \\
\mathbf{0 . 0 4 6}\end{array}$ & $\begin{array}{c}1.34(0.91-1.98) \\
0.17\end{array}$ \\
\hline & $\begin{array}{c}\text { ULBP2 } \\
\text { HR }(95 \% \text { CI) } \\
p \text {-value }\end{array}$ & $\begin{array}{c}2.14(1.45-3.17) \\
\mathbf{0 . 0 0 1}\end{array}$ & $\begin{array}{c}1.81(1.40-2.35) \\
\mathbf{0 . 0 0 0 1 5}\end{array}$ & $\begin{array}{c}2.75(1.10-6.89) \\
0.069\end{array}$ & $\begin{array}{c}1.78(1.05-3.03) \\
0.062\end{array}$ \\
\hline & $\begin{array}{c}\text { ULBP3 } \\
\text { HR ( } 95 \% \text { CI) } \\
p \text {-value }\end{array}$ & $\begin{array}{c}1.38(0.89-2.13) \\
0.18\end{array}$ & $\begin{array}{c}1.25(0.95-1.63) \\
0.12\end{array}$ & $\begin{array}{c}1.99(0.66-6.00) \\
0.27\end{array}$ & $\begin{array}{c}2.55(1.49-4.34) \\
\mathbf{0 . 0 0 2 3}\end{array}$ \\
\hline & $\begin{array}{c}\text { ULBP4 } \\
\text { HR ( } 95 \% \text { CI) } \\
p \text {-value }\end{array}$ & $\begin{array}{c}0.72(0.47-1.10) \\
0.18\end{array}$ & $\begin{array}{c}1.28(0.96-1.72) \\
0.12\end{array}$ & $\begin{array}{c}0.44(0.16-1.23) \\
0.20\end{array}$ & $\begin{array}{c}1.62(0.90-2.93) \\
0.15\end{array}$ \\
\hline & $\begin{array}{c}\text { VIM } \\
\text { HR ( } 95 \% \text { CI) } \\
p \text {-value }\end{array}$ & $\begin{array}{c}0.9(0.76-1.06) \\
0.22\end{array}$ & $\begin{array}{c}0.83(0.67-1.03) \\
0.12\end{array}$ & $\begin{array}{c}1.3(0.89-1.88) \\
0.26\end{array}$ & $\begin{array}{c}0.53(0.35-0.79) \\
\mathbf{0 . 0 0 6 4}\end{array}$ \\
\hline
\end{tabular}




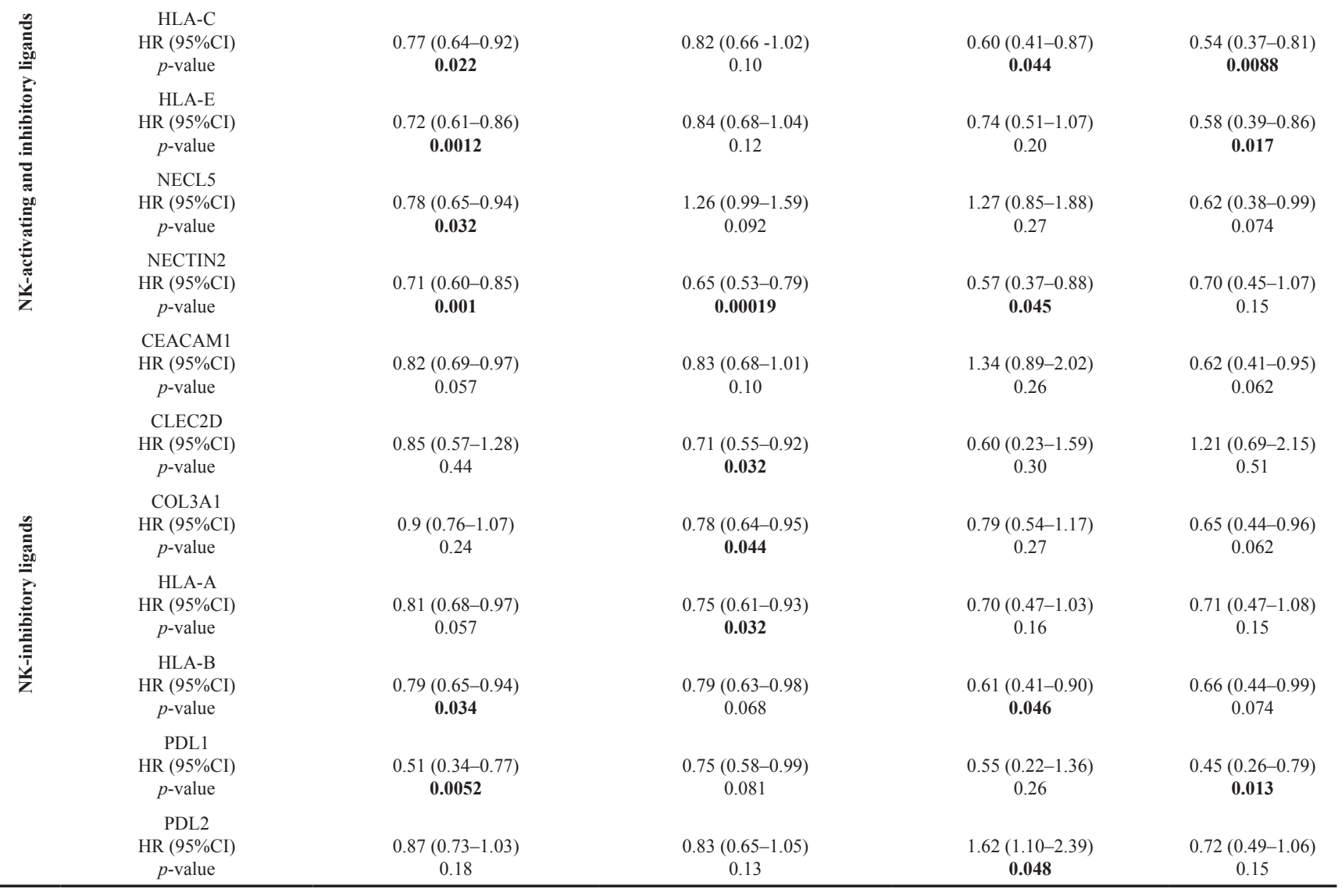

respectively (Figure 3A). However, no tendency could be observed for the ligands that can bind NK-inhibitory receptors.

\section{Association between the prognostic role of the mRNA expression of NK receptor ligands and the $\mathrm{BC}$ pathological grade}

In addition to the molecular subtype and lymph node status, the tumor pathological grade is another factor that affects treatment choice and cancer patient prognosis. In $\mathrm{BC}$, grades I, II and III are ascending indicators of how quickly a tumor is likely to grow and spread by describing the abnormality of the tumor tissue based on the tubular differentiation, nuclear features and mitotic activity of tumor cells. Therefore, we also checked whether the prognostic influence of NK receptor ligands might be affected by the breast tumor grade (Table 4 and Figure 4).

The NK-activating ligands B7-1, B7-2, CD48, CD58, CD72, MICB, SLAMF6, SLAMF7 and TNFSF9 were associated with longer RFS specifically in grade III tumors while AICL and CD27 were associated with longer RFS in grade II and grade III tumors. None of the NKactivating ligands was of favorable prognostic value in grade I tumors. The longer RFS that was associated with high mRNA expression of NK-activating ligands strongly correlated with longer OS for AICL (grade III only), B7-1,
B7-2, CD27 (grade III only), CD48, CD72, MICB, SLAMF7 and TNFSF9 (Table 4). On the other hand, high mRNA expression of MICA associated with shorter RFS and OS specifically in grade III tumors, whereas ULBP2 was associated with shorter OS specifically in grade III tumors (Table 4).

Overall, 11-10/21 (52.5-47.7\%) NK-activating ligands were associate with favorable RFS-OS in grade III BCs, 2-0/21 (9.5-0\%) in grade II and 0-0/20 (0-0\%) in grade $\mathrm{I}$ (Figure 4A).

Among the NK-inhibitory ligands, HLA-B was significantly associated with shorter RFS in grade I tumors but with longer RFS in grade III tumors. On the contrary, COL3A1 was significantly associated with shorter RFS and OS in grade III tumors but with longer RFS and OS in grade II tumors. On the other hand, HLA-A, PDL1, and PDL2 associated with longer RFS and OS specifically in grade III tumors (Table 4).

The NK-activating and inhibitory ligands were significantly associated with longer RFS in grade II and/ or grade III tumors (Table 4).

Taken together, as per NK-activating ligands, the favorable prognostic values of most NK-inhibitory and NK-activating and inhibitory ligands were associated with high grade BCs; $0-0 \%, 36.4-9 \%$ and $72.7-54.5 \%$ of these ligands associated with longer RFS-OS specifically in grade I, II and III BCs, respectively (Figure 4B). 


\section{Association between the prognostic role of the mRNA expression of NK receptor ligands and the p53 status in $\mathrm{BC}$ patients}

In $\mathrm{BC}$, mutations in the tumor suppressor gene $\mathrm{p} 53$ are present in $18-25 \%$ of primary BCs and are associated with more aggressive disease and worse prognosis $[135,136]$. In order to test whether the prognostic value of NK receptor ligands might be affected by the p53 status, the association between mRNA expression of these ligands and survival were analyzed in patients with p53 wild-type and p53 mutated BCs (Table 5).
A

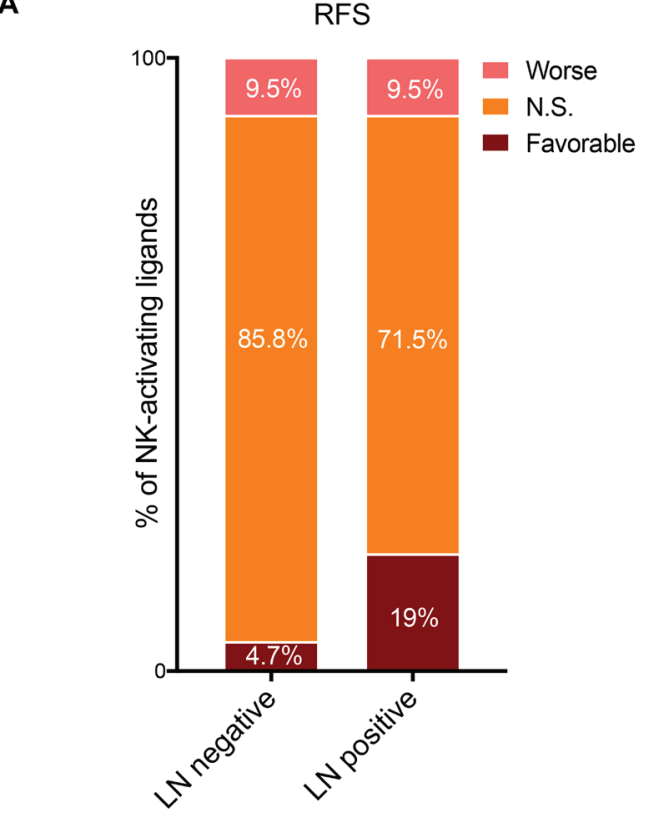

B

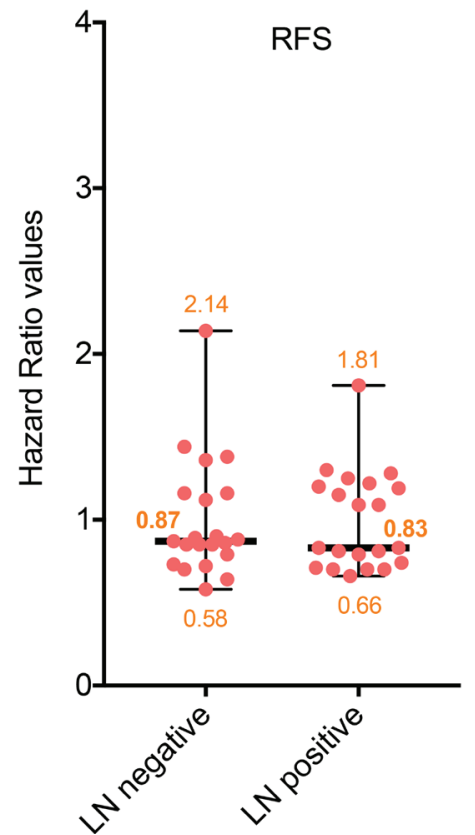

OS
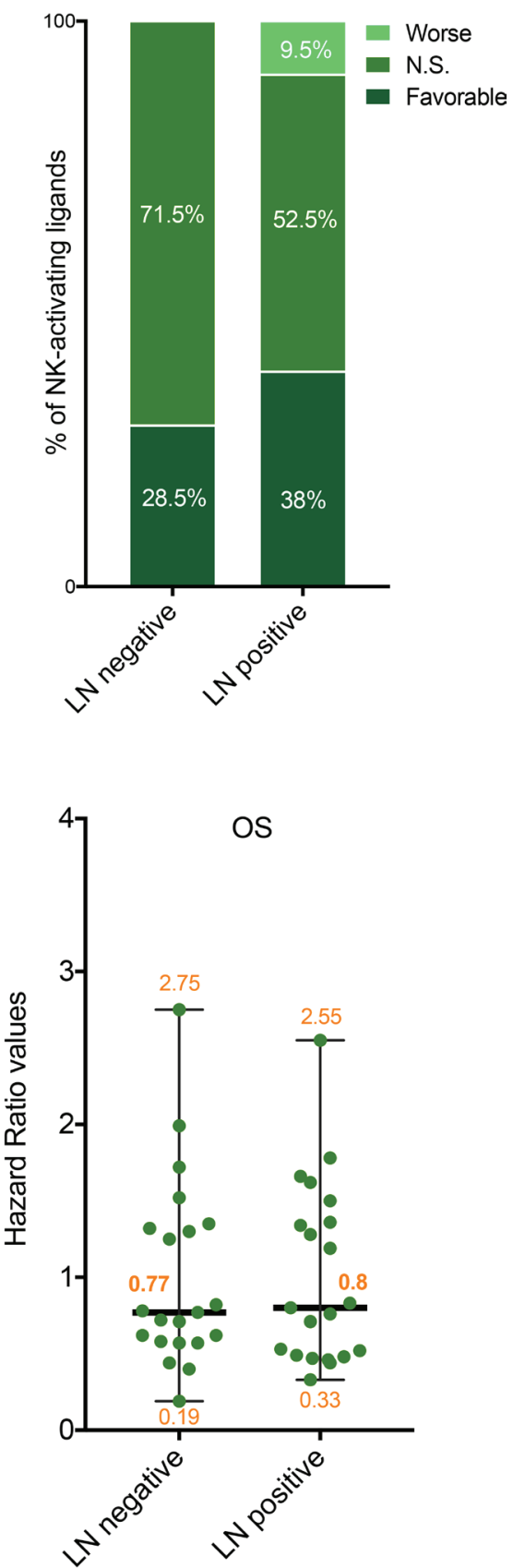

Figure 3: Prognostic values of the mRNA expression of NK-activating ligands depending on the lymph node status. (A) Percentages of the NK-activating ligands whose high mRNA expression significantly associated (Favorable and Worse) or not (N.S.) with RFS (Left graph) or OS (Right graph) in the different lymph node (LN) statuses. "Favorable" indicates the association of high mRNA expression with longer RFS/OS, representing good prognosis. "Worse" indicates the association of the high mRNA expression with shorter RFS/OS, representing bad prognosis. "N.S." indicates no significant association with prognosis. (B) Individual value plots visualizing the distribution of the hazard ratio (HR) values of the NK-activating ligands in LN negative and LN positive BC patients. The bars represent the median, lower and higher HR values for all ligands in each subtype. 
Table 4: Association between the prognostic role of mRNA expression of NK receptor ligands and tumor grade

\begin{tabular}{|c|c|c|c|c|c|c|c|}
\hline & \multirow{2}{*}{ Ligand } & \multicolumn{3}{|c|}{ RFS } & \multicolumn{3}{|c|}{ OS } \\
\hline & & I & II & III & I & II & III \\
\hline \multirow{21}{*}{ 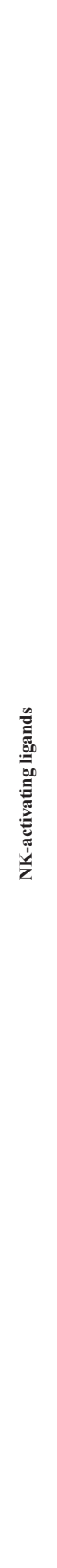 } & $\begin{array}{l}\text { AICL } \\
\text { HR }(95 \% \text { CI) } \\
p \text {-value }\end{array}$ & $\begin{array}{c}0.69(0.39-1.22) \\
0.29\end{array}$ & $\begin{array}{c}0.71(0.56-0.90) \\
\mathbf{0 . 0 3 9}\end{array}$ & $\begin{array}{c}0.77(0.62-0.96) \\
\mathbf{0 . 0 3 0 3}\end{array}$ & $\begin{array}{c}1.73(0.66-4.56) \\
0.33\end{array}$ & $\begin{array}{c}0.49(0.27-0.87) \\
0.076\end{array}$ & $\begin{array}{c}0.64(0.46-0.89) \\
\mathbf{0 . 0 1 6}\end{array}$ \\
\hline & $\begin{array}{l}\text { B7-1 } \\
\text { HR }(95 \% \mathrm{CI}) \\
p \text {-value }\end{array}$ & $\begin{array}{c}1.72(0.60-4.97) \\
0.34\end{array}$ & $\begin{array}{c}0.70(0.42-1.17) \\
0.209\end{array}$ & $\begin{array}{c}0.53(0.39-0.72) \\
\mathbf{0 . 0 0 0 1 8}\end{array}$ & $\begin{array}{c}0.14(0.01-1.64) \\
0.17\end{array}$ & $\begin{array}{c}0.47(0.15-1.48) \\
0.22\end{array}$ & $\begin{array}{c}0.33(0.18-0.58) \\
\mathbf{0 . 0 0 0 2 2}\end{array}$ \\
\hline & $\begin{array}{l}\mathrm{B} 7-2 \\
\text { HR }(95 \% \mathrm{CI}) \\
p \text {-value }\end{array}$ & $\begin{array}{c}0.62(0.37-1.05) \\
0.24\end{array}$ & $\begin{array}{c}0.83(0.66-1.06) \\
0.209\end{array}$ & $\begin{array}{c}0.74(0.57-0.95) \\
\mathbf{0 . 0 3 2}\end{array}$ & $\begin{array}{c}0.76(0.31-1.90) \\
0.56\end{array}$ & $\begin{array}{c}0.72(0.47-1.10) \\
0.19\end{array}$ & $\begin{array}{c}0.68(0.48-0.95) \\
\mathbf{0 . 0 4 0}\end{array}$ \\
\hline & $\begin{array}{l}\text { BAT3 } \\
\text { HR }(95 \% \mathrm{CI}) \\
p \text {-value }\end{array}$ & $\begin{array}{c}1.38(0.80-2.37) \\
0.33\end{array}$ & $\begin{array}{c}1.40(1.08-1.82) \\
0.054\end{array}$ & $\begin{array}{c}1.23(0.95-1.58) \\
0.12\end{array}$ & $\begin{array}{c}2.48(0.72-8.55) \\
0.22\end{array}$ & $\begin{array}{c}1.62(1.04-2.52) \\
0.099\end{array}$ & $\begin{array}{c}1.38(0.94-2.04) \\
0.13\end{array}$ \\
\hline & $\begin{array}{l}\text { CD27 } \\
\text { HR }(95 \% \text { CI) } \\
p \text {-value }\end{array}$ & $\begin{array}{c}0.63(0.37-1.06) \\
0.24\end{array}$ & $\begin{array}{c}0.72(0.56-0.91) \\
\mathbf{0 . 0 3 9}\end{array}$ & $\begin{array}{c}0.58(0.46-0.73) \\
\mathbf{0 . 0 0 0 0 1 6}\end{array}$ & $\begin{array}{c}0.31(0.11-0.88) \\
0.15\end{array}$ & $\begin{array}{c}0.69(0.45-1.05) \\
0.14\end{array}$ & $\begin{array}{c}0.44(0.32-0.61) \\
\mathbf{0 . 0 0 0 0 0 6 1}\end{array}$ \\
\hline & $\begin{array}{l}\text { CD48 } \\
\text { HR }(95 \% \text { CI) } \\
p \text {-value }\end{array}$ & $\begin{array}{c}0.71(0.42-1.18) \\
0.29\end{array}$ & $\begin{array}{c}0.74(0.58-0.94) \\
0.056\end{array}$ & $\begin{array}{c}0.60(0.46-0.77) \\
\mathbf{0 . 0 0 0 2 2}\end{array}$ & $\begin{array}{c}0.45(0.18-1.11) \\
0.17\end{array}$ & $\begin{array}{c}0.74(0.48-1.14) \\
0.22\end{array}$ & $\begin{array}{c}0.44(0.31-0.61) \\
\mathbf{0 . 0 0 0 0 0 6 1}\end{array}$ \\
\hline & $\begin{array}{l}\text { CD58 } \\
\text { HR }(95 \% \text { CI) } \\
p \text {-value }\end{array}$ & $\begin{array}{c}0.71(0.42-1.19) \\
0.29\end{array}$ & $\begin{array}{c}0.75(0.56-0.99) \\
0.102\end{array}$ & $\begin{array}{c}0.74(0.59-0.92) \\
\mathbf{0 . 0 1 4}\end{array}$ & $\begin{array}{c}2.29(0.92-5.7) \\
0.17\end{array}$ & $\begin{array}{c}0.59(0.38-0.92) \\
0.076\end{array}$ & $\begin{array}{c}0.74(0.54-1.03) \\
0.11\end{array}$ \\
\hline & $\begin{array}{l}\text { CD70 } \\
\text { HR }(95 \% \mathrm{CI}) \\
p \text {-value }\end{array}$ & $\begin{array}{c}0.76(0.44-1.31) \\
0.34\end{array}$ & $\begin{array}{c}0.81(0.60-1.09) \\
0.209\end{array}$ & $\begin{array}{c}0.78(0.60-1.02) \\
0.088\end{array}$ & $\begin{array}{c}0.40(0.11-1.37) \\
0.22\end{array}$ & $\begin{array}{c}1.81(1.17-2.78) \\
0.076\end{array}$ & $\begin{array}{c}0.78(0.55-1.12) \\
0.21\end{array}$ \\
\hline & $\begin{array}{l}\text { CD72 } \\
\text { HR }(95 \% \mathrm{CI}) \\
p \text {-value }\end{array}$ & $\begin{array}{c}1.71(1.01-2.90) \\
0.22\end{array}$ & $\begin{array}{c}0.88(0.69-1.11) \\
0.28\end{array}$ & $\begin{array}{c}0.70(0.53-0.91) \\
\mathbf{0 . 0 1 8}\end{array}$ & $\begin{array}{c}2.21(0.90-5.43) \\
0.17\end{array}$ & $\begin{array}{c}0.74(0.48-1.14) \\
0.22\end{array}$ & $\begin{array}{c}0.52(0.35-0.77) \\
\mathbf{0 . 0 0 2 8}\end{array}$ \\
\hline & $\begin{array}{l}\text { KMT2E } \\
\text { HR }(95 \% \text { CI) } \\
p \text {-value }\end{array}$ & $\begin{array}{c}4.18(0.55-31.97) \\
0.27\end{array}$ & $\begin{array}{c}0.65(0.38-1.09) \\
0.18\end{array}$ & $\begin{array}{c}1.49(1.09-2.04) \\
\mathbf{0 . 0 2 0 7}\end{array}$ & $\begin{array}{c}0(0-\text { inf }) \\
0.17\end{array}$ & $\begin{array}{c}0.13(0.02-0.98) \\
0.076\end{array}$ & $\begin{array}{c}1.42(0.78-2.58) \\
0.27\end{array}$ \\
\hline & $\begin{array}{l}\text { MICA } \\
\text { HR }(95 \% \mathrm{CI}) \\
p \text {-value }\end{array}$ & $\begin{array}{c}1.30(0.76-2.23) \\
0.35\end{array}$ & $\begin{array}{c}1.16(0.92-1.48) \\
0.23\end{array}$ & $\begin{array}{c}1.57(1.26-1.97) \\
\mathbf{0 . 0 0 0 2 2}\end{array}$ & $\begin{array}{c}2.09(0.80-5.43) \\
0.22\end{array}$ & $\begin{array}{c}0.67(0.43-1.05) \\
0.14\end{array}$ & $\begin{array}{c}1.97(1.41-2.75) \\
\mathbf{0 . 0 0 0 2 2}\end{array}$ \\
\hline & $\begin{array}{l}\text { MICB } \\
\text { HR }(95 \% \mathrm{CI}) \\
p \text {-value }\end{array}$ & $\begin{array}{c}0.71(0.41-1.20) \\
0.29\end{array}$ & $\begin{array}{c}0.76(0.58-0.99) \\
0.102\end{array}$ & $\begin{array}{c}0.73(0.59-0.91) \\
\mathbf{0 . 0 1 0 5}\end{array}$ & $\begin{array}{c}0.57(0.23-1.43) \\
0.32\end{array}$ & $\begin{array}{c}0.75(0.49-1.15) \\
0.22\end{array}$ & $\begin{array}{c}0.64(0.46-0.89) \\
\mathbf{0 . 0 1 7}\end{array}$ \\
\hline & $\begin{array}{l}\text { NECL2 } \\
\text { HR }(95 \% \text { CI) } \\
p \text {-value }\end{array}$ & $\begin{array}{c}0.47(0.28-0.80) \\
0.065\end{array}$ & $\begin{array}{c}0.75(0.59-0.96) \\
0.074\end{array}$ & $\begin{array}{c}1.21(0.97-1.51) \\
0.107\end{array}$ & $\begin{array}{c}0.25(0.07-0.86) \\
0.15\end{array}$ & $\begin{array}{c}0.60(0.39-0.93) \\
0.078\end{array}$ & $\begin{array}{c}1.26(0.90-1.75) \\
0.209\end{array}$ \\
\hline & $\begin{array}{l}\text { SLAMF6 } \\
\text { HR }(95 \% \text { CI) } \\
p \text {-value }\end{array}$ & $\begin{array}{c}0.42(0.14-1.20) \\
0.24\end{array}$ & $\begin{array}{c}0.67(0.40-1.12) \\
0.209\end{array}$ & $\begin{array}{c}0.52(0.38-0.71) \\
\mathbf{0 . 0 0 0 1 2}\end{array}$ & $\begin{array}{c}0(0-\text { inf }) \\
0.17\end{array}$ & $\begin{array}{c}5.84(0.75-45.29) \\
0.11\end{array}$ & $\begin{array}{c}0.76(0.45-1.28) \\
0.309\end{array}$ \\
\hline & $\begin{array}{l}\text { SLAMF7 } \\
\text { HR }(95 \% \mathrm{CI}) \\
p \text {-value }\end{array}$ & $\begin{array}{c}1.84(0.58-5.86) \\
0.34\end{array}$ & $\begin{array}{c}0.68(0.41-1.13) \\
0.209\end{array}$ & $\begin{array}{c}0.51(0.37-0.70) \\
\mathbf{0 . 0 0 0 1 2}\end{array}$ & $\begin{array}{c}0.21(0.02-2.29) \\
0.22\end{array}$ & $\begin{array}{c}0.47(0.15-1.50) \\
0.22\end{array}$ & $\begin{array}{c}0.31(0.18-0.55) \\
\mathbf{0 . 0 0 0 1 2}\end{array}$ \\
\hline & $\begin{array}{l}\text { TNFSF9 } \\
\text { HR }(95 \% \text { CI) } \\
p \text {-value }\end{array}$ & $\begin{array}{c}0.73(0.43-1.22) \\
0.32\end{array}$ & $\begin{array}{c}0.83(0.64-1.07) \\
0.209\end{array}$ & $\begin{array}{c}0.75(0.60-0.94) \\
\mathbf{0 . 0 2 0 7}\end{array}$ & $\begin{array}{c}0.57(0.21-1.52) \\
0.33\end{array}$ & $\begin{array}{c}1.56(0.99-2.46) \\
0.11\end{array}$ & $\begin{array}{c}0.67(0.47-0.95) \\
\mathbf{0 . 0 4 0 4}\end{array}$ \\
\hline & $\begin{array}{l}\text { ULBP1 } \\
\text { HR }(95 \% \mathrm{CI}) \\
p \text {-value }\end{array}$ & $\begin{array}{c}0.65(0.34-1.23) \\
0.29\end{array}$ & $\begin{array}{c}0.84(0.66-1.07) \\
0.209\end{array}$ & $\begin{array}{c}0.84(0.67-1.05) \\
0.12\end{array}$ & $\begin{array}{c}0.47(0.17-1.34) \\
0.22\end{array}$ & $\begin{array}{c}1.36(0.88-2.11) \\
0.22\end{array}$ & $\begin{array}{c}0.80(0.54-1.19) \\
0.28\end{array}$ \\
\hline & $\begin{array}{l}\text { ULBP2 } \\
\text { HR }(95 \% \text { CI) } \\
p \text {-value }\end{array}$ & $\begin{array}{c}0.49(0.17-1.47) \\
0.29\end{array}$ & $\begin{array}{c}1.80(1.06-3.06) \\
0.081\end{array}$ & $\begin{array}{c}1.46(1.04-2.05) \\
\mathbf{0 . 0 3 7}\end{array}$ & $\begin{array}{c}7.04(0.61-81.25) \\
0.17\end{array}$ & $\begin{array}{c}0.24(0.05-1.11) \\
0.11\end{array}$ & $\begin{array}{c}2.05(1.20-3.48) \\
\mathbf{0 . 0 1 6}\end{array}$ \\
\hline & $\begin{array}{l}\text { ULBP3 } \\
\text { HR }(95 \% \mathrm{CI}) \\
p \text {-value }\end{array}$ & $\begin{array}{c}0.69(0.23-2.07) \\
0.51\end{array}$ & $\begin{array}{c}1.22(0.73-2.04) \\
0.44\end{array}$ & $\begin{array}{c}1.28(0.93-1.75) \\
0.13\end{array}$ & $\begin{array}{c}0.24(0.01-3.78) \\
0.33\end{array}$ & $\begin{array}{c}3.65(1.17-11.39) \\
0.076\end{array}$ & $\begin{array}{c}2.07(1.05-4.08) \\
0.052\end{array}$ \\
\hline & $\begin{array}{l}\text { ULBP4 } \\
\text { HR }(95 \% \text { CI) } \\
p \text {-value }\end{array}$ & $\begin{array}{c}0.39(0.12-1.23) \\
0.24\end{array}$ & $\begin{array}{c}1.43(0.86-2.37) \\
0.209\end{array}$ & $\begin{array}{c}0.77(0.55-1.09) \\
0.14\end{array}$ & $\begin{array}{c}0 \text { (0-inf) } \\
0.15\end{array}$ & $\begin{array}{c}0.54(0.16-1.81) \\
0.33\end{array}$ & $\begin{array}{c}1.43(0.81-2.52) \\
0.25\end{array}$ \\
\hline & $\begin{array}{l}\text { VIM } \\
\text { HR }(95 \% \mathrm{CI}) \\
p \text {-value }\end{array}$ & $\begin{array}{c}0.76(0.44-1.31) \\
0.34\end{array}$ & $\begin{array}{c}1.2(0.91-1.58) \\
0.23\end{array}$ & $\begin{array}{c}0.83(0.65-1.05) \\
0.12\end{array}$ & $\begin{array}{c}2.18(0.89-5.35) \\
0.17\end{array}$ & $\begin{array}{c}0.66(0.43-1.03) \\
0.12\end{array}$ & $\begin{array}{c}0.64(0.46-0.91) \\
\mathbf{0 . 0 2 2}\end{array}$ \\
\hline \multirow{4}{*}{ 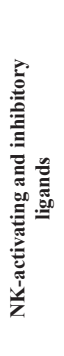 } & $\begin{array}{l}\text { HLA-C } \\
\text { HR }(95 \% \text { CI }) \\
p \text {-value }\end{array}$ & $\begin{array}{c}1.83(1.08-3.10) \\
0.18\end{array}$ & $\begin{array}{c}0.76(0.59-0.97) \\
0.081\end{array}$ & $\begin{array}{c}0.54(0.44-0.67) \\
\mathbf{0 . 0 0 0 0 0 0 7 6 8}\end{array}$ & $\begin{array}{c}0.62(0.25-1.59) \\
0.37\end{array}$ & $\begin{array}{c}1.25(0.78-2.01) \\
0.36\end{array}$ & $\begin{array}{c}0.42(0.30-0.58) \\
\mathbf{0 . 0 0 0 0 0 2 5}\end{array}$ \\
\hline & $\begin{array}{l}\text { HLA-E } \\
\text { HR }(95 \% \mathrm{CI}) \\
p \text {-value }\end{array}$ & $\begin{array}{c}0.65(0.39-1.09) \\
0.24\end{array}$ & $\begin{array}{c}0.72(0.56-0.92) \\
\mathbf{0 . 0 4 2}\end{array}$ & $\begin{array}{c}0.67(0.54-0.84) \\
\mathbf{0 . 0 0 0 8 8}\end{array}$ & $\begin{array}{c}0.54(0.22-1.35) \\
0.26\end{array}$ & $\begin{array}{c}0.65(0.42-1.00) \\
0.11\end{array}$ & $\begin{array}{c}0.50(0.36-0.69) \\
\mathbf{0 . 0 0 0 1 2}\end{array}$ \\
\hline & $\begin{array}{l}\text { NECL5 } \\
\text { HR }(95 \% \text { CI }) \\
p \text {-value }\end{array}$ & $\begin{array}{c}1.33(0.77-2.30) \\
0.34\end{array}$ & $\begin{array}{c}0.68(0.52-0.88) \\
\mathbf{0 . 0 3 9}\end{array}$ & $\begin{array}{c}0.79(0.63-0.98) \\
\mathbf{0 . 0 4 1}\end{array}$ & $\begin{array}{c}0.67(0.25-1.77) \\
0.43\end{array}$ & $\begin{array}{c}1.8(1.1-2.95) \\
0.076\end{array}$ & $\begin{array}{c}0.72(0.5-1.05) \\
0.12\end{array}$ \\
\hline & $\begin{array}{l}\text { NECTIN2 } \\
\text { HR }(95 \% \text { CI) } \\
p \text {-value }\end{array}$ & $\begin{array}{c}0.62(0.32-1.19) \\
0.29\end{array}$ & $\begin{array}{c}0.64(0.50-0.81) \\
\mathbf{0 . 0 0 8}\end{array}$ & $\begin{array}{c}0.82(0.65-1.03) \\
0.11\end{array}$ & $\begin{array}{c}1.64(0.52-5.12) \\
0.43\end{array}$ & $\begin{array}{c}0.70(0.46-1.09) \\
0.18\end{array}$ & $\begin{array}{c}1.28(0.92-1.79) \\
0.17\end{array}$ \\
\hline
\end{tabular}




\begin{tabular}{|c|c|c|c|c|c|c|c|}
\hline \multirow{7}{*}{ 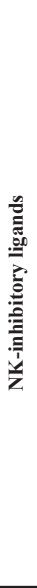 } & $\begin{array}{l}\text { CEACAM1 } \\
\text { HR }(95 \% \mathrm{CI}) \\
p \text {-value }\end{array}$ & $\begin{array}{c}1.79(1.03-3.13) \\
0.22\end{array}$ & $\begin{array}{c}1.23(0.96-1.57) \\
0.18\end{array}$ & $\begin{array}{c}0.77(0.61-0.97) \\
\mathbf{0 . 0 3 7}\end{array}$ & $\begin{array}{c}1.51(0.60-3.80) \\
0.42\end{array}$ & $\begin{array}{c}1.37(0.87-2.16) \\
0.22\end{array}$ & $\begin{array}{c}0.76(0.53-1.08) \\
0.17\end{array}$ \\
\hline & $\begin{array}{l}\text { CLEC2D } \\
\text { HR }(95 \% \mathrm{CI}) \\
p \text {-value }\end{array}$ & $\begin{array}{c}1.90(0.53-6.81) \\
0.34\end{array}$ & $\begin{array}{c}1.50(0.87-2.58) \\
0.209\end{array}$ & $\begin{array}{c}0.76(0.54-1.07) \\
0.12\end{array}$ & $\begin{array}{c}0(0-\text { inf }) \\
0.17\end{array}$ & $\begin{array}{c}0.58(0.17-1.94) \\
0.37\end{array}$ & $\begin{array}{c}1.25(0.70-2.21) \\
0.45\end{array}$ \\
\hline & $\begin{array}{l}\text { COL3A1 } \\
\text { HR }(95 \% \mathrm{CI}) \\
p \text {-value }\end{array}$ & $\begin{array}{c}0.45(0.25-0.82) \\
0.076\end{array}$ & $\begin{array}{c}0.71(0.56-0.91) \\
\mathbf{0 . 0 3 9}\end{array}$ & $\begin{array}{c}1.55(1.24-1.93) \\
\mathbf{0 . 0 0 0 2 3}\end{array}$ & $\begin{array}{c}0.33(0.12-0.91) \\
0.15\end{array}$ & $\begin{array}{c}0.5(0.32-0.76) \\
\mathbf{0 . 0 3 8}\end{array}$ & $\begin{array}{c}1.66(1.18-2.34) \\
\mathbf{0 . 0 0 8 5}\end{array}$ \\
\hline & $\begin{array}{l}\text { HLA-A } \\
\text { HR }(95 \% \mathrm{CI}) \\
p \text {-value }\end{array}$ & $\begin{array}{c}1.59(0.93-2.73) \\
0.24\end{array}$ & $\begin{array}{c}0.81(0.64-1.03) \\
0.18\end{array}$ & $\begin{array}{c}0.56(0.45-0.70) \\
\mathbf{0 . 0 0 0 0 0 3 5}\end{array}$ & $\begin{array}{c}0.67(0.26-1.78) \\
0.43\end{array}$ & $\begin{array}{c}1.32(0.83-2.10) \\
0.26\end{array}$ & $\begin{array}{c}0.49(0.35-0.68) \\
\mathbf{0 . 0 0 0 0 9 6}\end{array}$ \\
\hline & $\begin{array}{l}\text { HLA-B } \\
\text { HR }(95 \% \mathrm{CI}) \\
p \text {-value }\end{array}$ & $\begin{array}{c}2.36(1.41-3.95) \\
\mathbf{0 . 0 2 5}\end{array}$ & $\begin{array}{c}0.77(0.60-0.98) \\
0.082\end{array}$ & $\begin{array}{c}0.58(0.46-0.72) \\
\mathbf{0 . 0 0 0 0 1 1}\end{array}$ & $\begin{array}{c}2.16(0.87-5.41) \\
0.18\end{array}$ & $\begin{array}{c}0.58(0.37-0.9) \\
0.076\end{array}$ & $\begin{array}{c}0.51(0.36-0.71) \\
\mathbf{0 . 0 0 0 2 3}\end{array}$ \\
\hline & $\begin{array}{l}\text { PDL1 } \\
\text { HR }(95 \% \mathrm{CI}) \\
p \text {-value }\end{array}$ & $\begin{array}{c}0.40(0.14-1.15) \\
0.24\end{array}$ & $\begin{array}{c}0.75(0.45-1.25) \\
0.28\end{array}$ & $\begin{array}{c}0.46(0.34-0.63) \\
\mathbf{0 . 0 0 0 0 0 7 5}\end{array}$ & $\begin{array}{c}0(0-\text { inf }) \\
0.15\end{array}$ & $\begin{array}{c}0.53(0.17-1.68) \\
0.29\end{array}$ & $\begin{array}{c}0.33(0.18-0.60) \\
\mathbf{0 . 0 0 0 3 2}\end{array}$ \\
\hline & $\begin{array}{l}\text { PDL2 } \\
\text { HR }(95 \% \mathrm{CI}) \\
p \text {-value }\end{array}$ & $\begin{array}{c}1.53(0.91-2.57) \\
0.25\end{array}$ & $\begin{array}{c}1.19(0.92-1.53) \\
0.22\end{array}$ & $\begin{array}{c}0.76(0.61-0.95) \\
\mathbf{0 . 0 2 4}\end{array}$ & $\begin{array}{c}2.40(0.94-6.09) \\
0.17\end{array}$ & $\begin{array}{c}1.75(1.02-3.02) \\
0.11\end{array}$ & $\begin{array}{c}0.67(0.48-0.93) \\
\mathbf{0 . 0 3 0 1}\end{array}$ \\
\hline
\end{tabular}

The prognostic values of individual NK-activating ligands differentially associated with the p53 status (Table 5). For example, AICL, CD48, and MICB were associated with longer RFS in both p53 wild-type and p53 mutated BCs (Table 5) which correlated with longer OS for only CD48 (p53 mutated). However, B7-1, B7-2, CD27, CD72, SLAMF6 and SLAMF7 were associated with longer RFS specifically in p53 mutated BCs, which correlated with OS for all except for B7-1 and SLAMF6. In contrast, high mRNA expression of MICA correlated with longer RFS specifically in $\mathrm{p} 53$ wild-type BCs without any significant association with OS. As for the NKactivating ligands that correlated with worse prognosis, ULBP3 on the one hand and ULBP2 on the other hand were associated with shorter RFS specifically in p53 wild-type or p53 mutated BCs, respectively (Table 5). Regarding the ligands that can bind NK-inhibitory receptors, they were mostly associated with longer RFS in p53 mutated BCs (Table 5).

\section{DISCUSSION}

Despite a significant piece of experimental and clinical evidence supporting the role of NK cells in $\mathrm{BC}$ control, $\mathrm{BC}$ still develops and progresses to form large tumors and metastases [22, 25-33]. Several mechanisms of cancer escape from NK immunity were proposed [137]. Among these, BC cells modulate their immunogenicity mainly by altering the expression of ligands for NK cell activating and inhibitory receptors; thereby stimulating a state of immunological tolerance by rendering themselves invisible to NK cells. This mechanism of cancer cell escape from NK immunity is frequently observed in solid tumors including BC [137], which suggests that NK receptor ligands' expression may have prognostic significance in $\mathrm{BC}$ patients and may help identify candidates for NK-based immunotherapies. Therefore, in the present study, we firstly performed systematic literature screening to identify and select all NK-regulatory ligands for NK receptors known to date. In total, we identified 39 ligands for NK activating and inhibitory receptors. Then, we utilized the KM plotter platform to investigate whether the expression of these ligands may influence RFS and OS, and predict prognosis in $\mathrm{BC}$ patients and whether these effects may differ by molecular subtypes and other clinicopathological features.

Among the 21 analyzed NK-activating ligands, the high expression of $16(80 \%)$ ligands significantly correlated with better RFS in all BCs, suggesting a protective role of these ligands against cancer progression. However, while the longer RFS correlated with longer OS for about half of these NK-activating ligands, the results showed no significant difference in the OS between the two groups of patients with different expression levels of B7-1, B7-2, CD70, MICB, TNFSF9, ULBP1, and ULBP4 or showed worse OS for high expression of MICA and ULBP3 ligands. This absence of correlation between better RFS and OS can be the consequence of the limited efficacy of the second line therapy in the group of patients with high expression of these ligands. This limited treatment efficacy can also be the result of a first line therapy-induced selective advantage of recurrent tumors that are resistant to the subsequent treatments, thereby accelerating cancer progression and patient death. Therefore, patient management should be optimized after relapse or even before to prevent later recurrence of more aggressive tumor. In this regard, NK-based therapy such as the adoptive transfer of NK cells expressing (endogenously or by genetic engineering) the activating receptors for these ligands might be a potential strategy to improve OS of these patients. However, if the treatment is considered after relapse, the maintenance of the expression of the NK receptor ligands in the secondary tumor should be tested. Furthermore, as mRNA expression does not necessarily correlate with protein expression in all cases, the expression of a considered ligand should also be tested at the protein level to predict a potential response to an NK-based treatment.

On the other hand, other NK-activating ligands (i.e. BAT3, CD58, and ULBP2) were unexpectedly associated with worse prognosis suggesting that these ligands are markers of more aggressive tumors. Although the high 
expression of these ligands is expected to enhance tumor cell elimination by NK cells, these lymphocytes might be either absent in these tumors or unresponsive to these ligands. The possible unresponsiveness of NK cells to these ligands expressed by cancer cells can be the consequence of tumor-induced deregulation of the expression of their cognate receptors on the surface of the NK cells. In fact, $\mathrm{BC}$ cells can release immunosuppressive molecules such as transforming growth factor- $\beta 1$ (TGF- $\beta 1$ ) and soluble MICAs that can downregulate the activating receptors and upregulate the inhibitory receptors on NK cells, as a mechanism of tumor escape from immune surveillance [137]. Another hypothesis might be that in addition to their role as ligands for NK-activating receptors, these genes might also have another $\mathrm{NK}$-independent pro-oncogenic function, which confers increased aggressiveness to the tumor cells. Accordingly, BAT3 has been shown to play a role in the induction of the cell cycle progression by regulating p21 protein [138] and protection from apoptosis by inducing the anti-apoptotic YWK-II/APLP2 protein
A

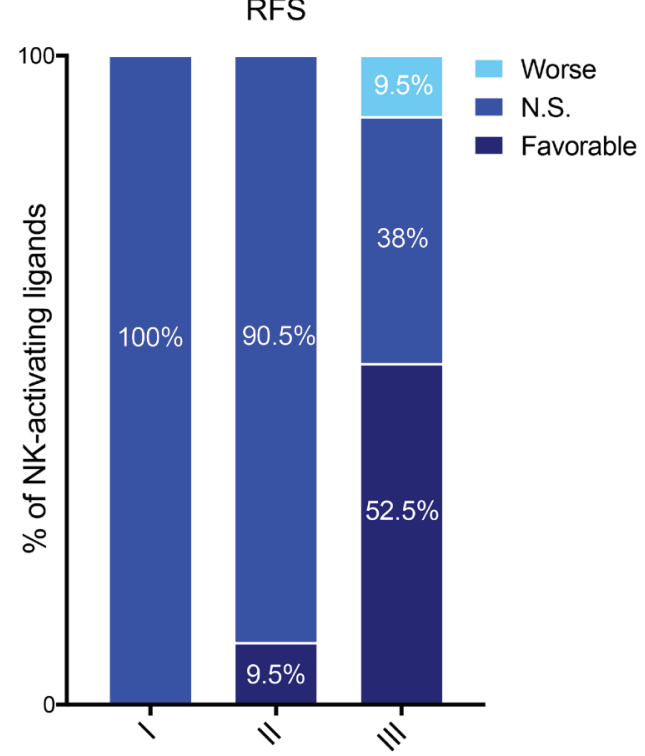

B

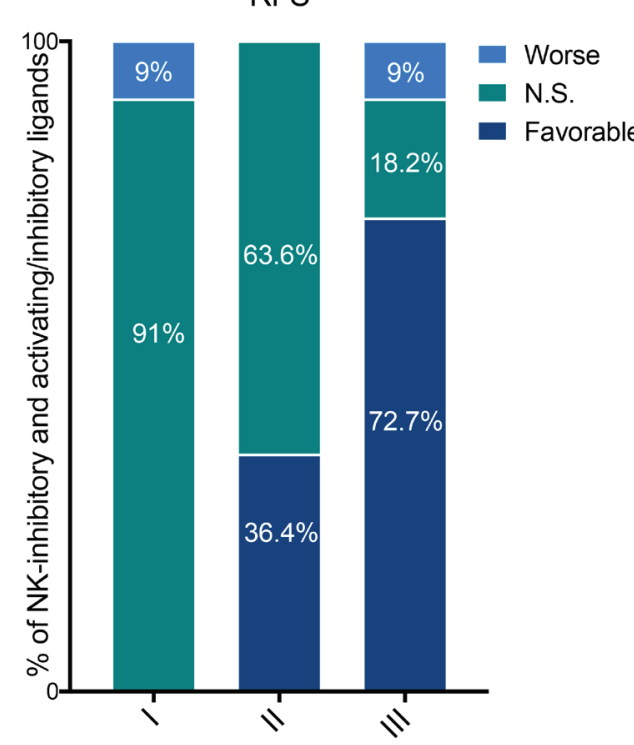

OS
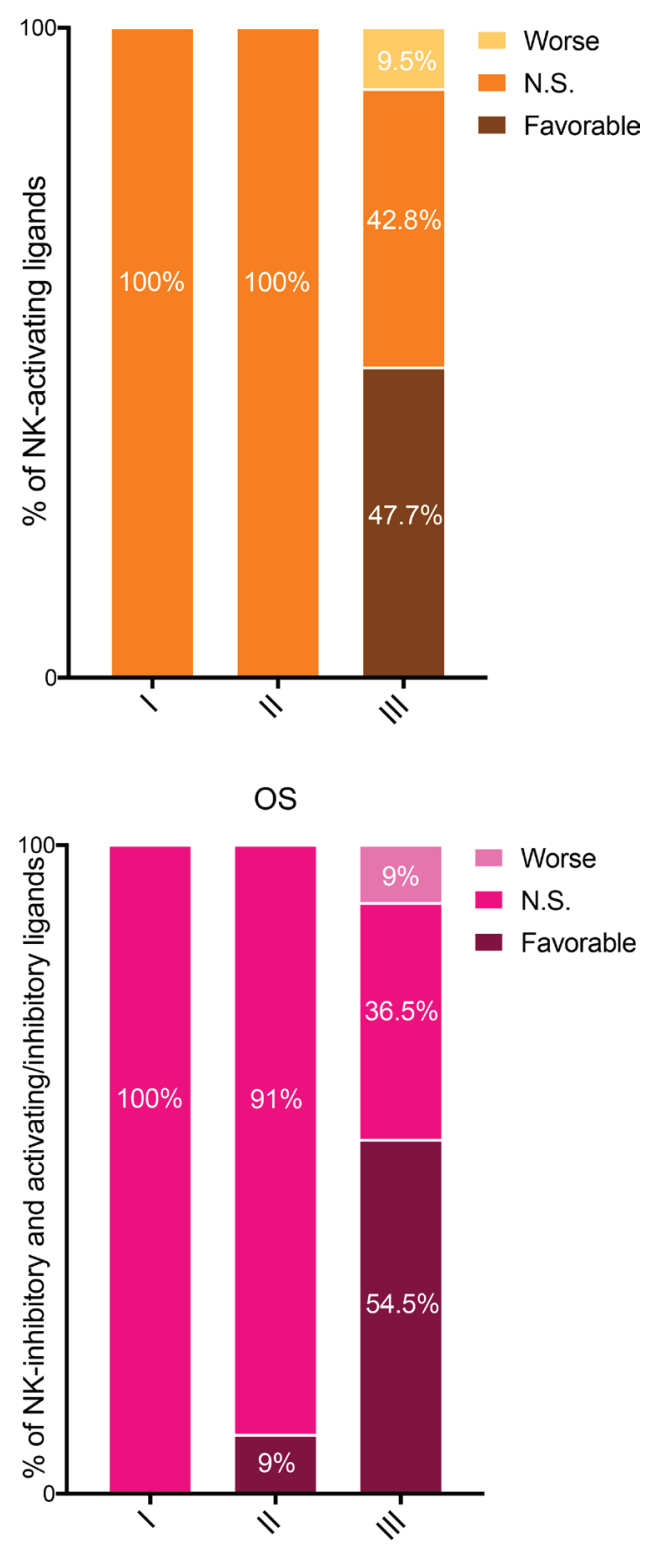

Figure 4: Prognostic values of the mRNA expression of NK-activating ligands depending on the tumor pathological grade. (A) Percentages of the NK-activating ligands whose high mRNA expression significantly associated (Favorable and Worse) or not (N.S.) with RFS (Left graph) or OS (Right graph) in the different tumor grades. "Favorable" indicates the association of high mRNA expression with longer RFS/OS, representing good prognosis. "Worse" indicates the association of the high mRNA expression with shorter RFS/OS, representing bad prognosis. "N.S." indicates no significant association with prognosis. (B) Same as in panel "a" but for NK-inhibitory ligands together with the ligands that can bind both NK-activating and inhibitory receptors (i.e. NK-activating/inhibitory ligands). 
Table 5: Association between the prognostic role of mRNA expression of NK receptor ligands and p53 status

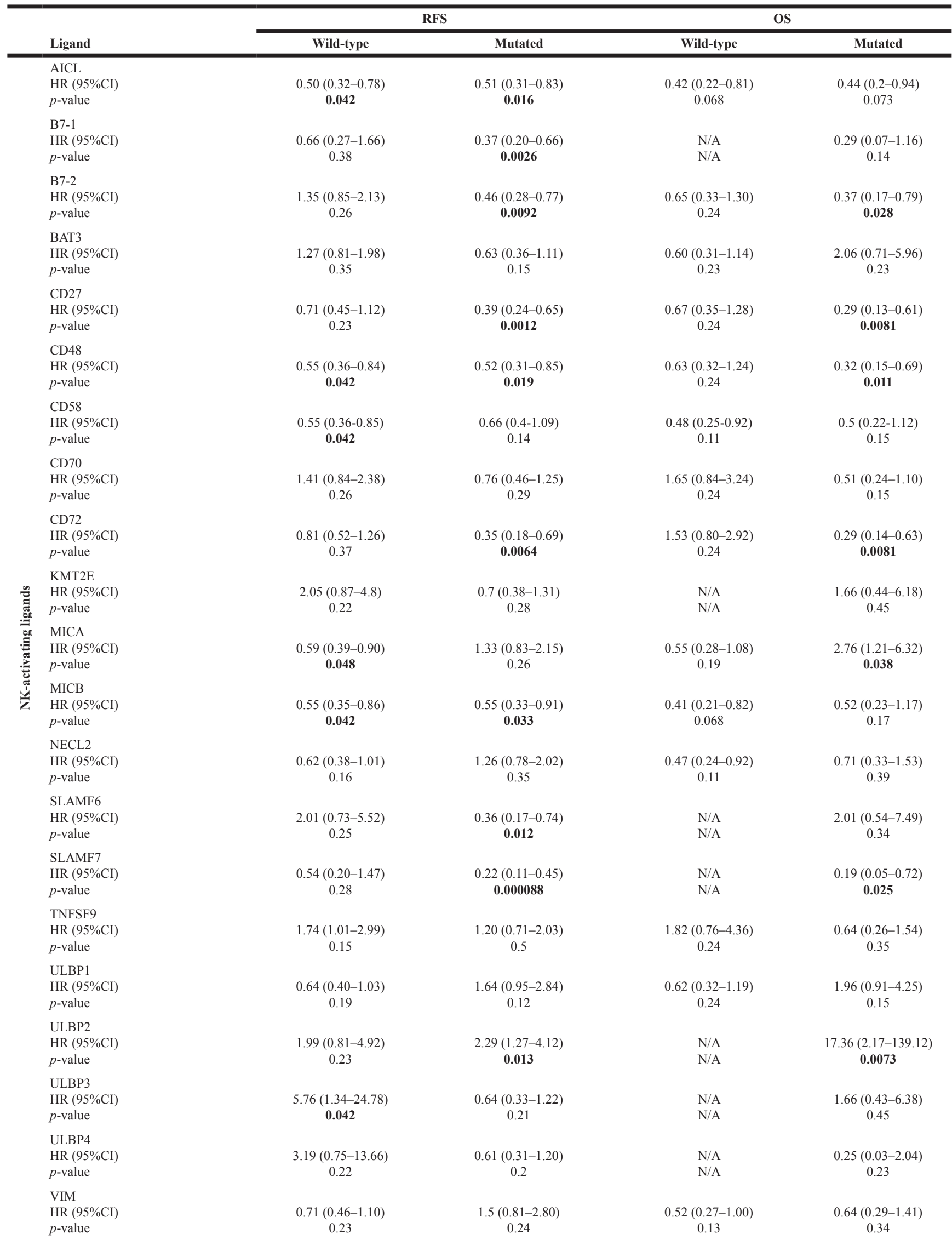




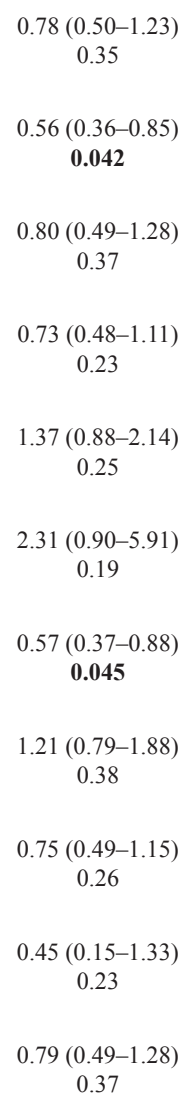

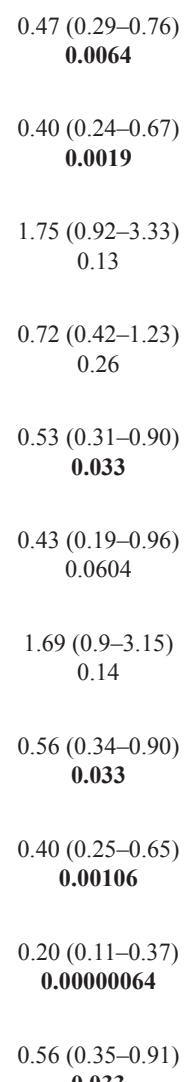

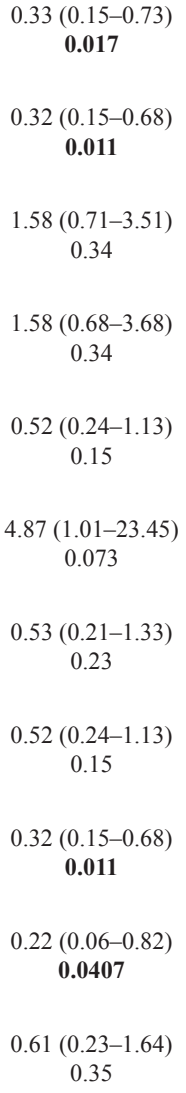

stability [139]. Furthermore, CD58 can promote the selfrenewal of tumor-initiating cells by upregulating the Wnt/ $\beta$-catenin pathway [140]. However, to our knowledge, no NK-independent oncogenic function of ULBP2 has been identified to date. Whatever the mechanism involved, the association of these NK-activating ligands with shorter time to relapse and survival suggests that $\mathrm{BC}$ patients expressing high levels of BAT3, CD58, or ULBP2 may be favorable candidates for NK-cell based therapy. A possible therapy would be the adoptive transfer of NK cells expressing receptors for these ligands (i.e. NKp30, $\mathrm{CD} 2$, or NKG2D) to induce the elimination of residual tumor cells, prevent relapse and improve patient survival.

Since the activity of NK cells is negatively regulated by the engagement of their inhibitory receptors, high expression of the NK-inhibitory ligands (CEACAM1, CLEC2D, HLA-A, HLA-B, PDL1, and PDL2) was expected to be associated with worse prognosis. However, except for COL3A1, the NK-inhibitory ligands were associated with favorable prognosis, suggesting that these ligands might have a cancer-protective role in addition to their function as NK-inhibitory ligands. Indeed, the expression of MHC class I molecules (HLA-A, HLA-B, and HLA-C) on cancer cells allows their detection and destruction by $\mathrm{T}$ cell lymphocytes [141]. Accordingly, downregulation or loss of these molecules in $\mathrm{BC}$ and other cancers increases metastasis to the lymph nodes and other organs [142]. Furthermore, CEACAM1 is an adhesion molecule that is regarded as a tumor suppressor and was found to regulate tumor growth and apoptosis in many types of cancer including BC $[143,144]$. On the other hand, although PDL1 expression by tumor cells is believed to mediate inhibition of local immune response by down-modulating tumor-infiltrating lymphocyte (TIL), including NK and T cell, function, survival, and expansion [145], our study defines high PDL1 expression as a positive prognostic biomarker in $\mathrm{BC}$, in agreement with other studies [146, 147]. This survival result might be due to the presence of a strong antitumor immune response leading to PDL1 expression. In fact, it has been shown that TILs can release cytokines including interferon- $\gamma$ that upregulate PDL1 expression on tumor cells $[145,146,148-150]$; thus indicating a strong anti-tumor immune response.

Importantly, our finding that high expression of most ligands for NK-inhibitory receptors is associated with favorable prognosis and accordingly low expression of these ligands is associated with worse prognosis is of high therapeutic interest. In fact, this finding suggests that in patients with worse prognosis, the low expression of NK-inhibitory ligands would reduce the inhibitory signals for NK cell activation and enhance their cytotoxic potential towards tumor cells; thereby increasing the chances of response to NK-based therapy. Accordingly, we suggest that $\mathrm{BC}$ patients with tumors expressing high levels of the NK-activating ligands that would mark worse 
prognosis or limited OS (such as BAT3, CD58, ULBP2, MICA, ULBP3, B7-1, B7-2, CD70, MICB, TNFSF9, ULBP1 and ULBP4), would probably have tumors with low expression of NK-inhibitory ligands (which should be tested and confirmed in the tumor), making them ideal candidates for a successful NK-based immunotherapy.

Analysis of the association between the prognostic role of the mRNA expression of NK receptor ligands and the different $\mathrm{BC}$ subtypes showed that the prognostic influence of CD27, CD48, MICB, SLAMF6, TNFSF9, ULBP1, HLA-C, NECL5, COL3A1, HLA-B, PDL1, and PDL2 is independent of the BC molecular subtype whereas the effect of the other NK receptor ligands on patient relapse and survival may vary between the different $\mathrm{BC}$ subtypes. Interestingly, the favorable prognostic influence of NK-activating ligands, as a whole, is higher in basal-like and HER2 types in comparison to luminal $\mathrm{A} / \mathrm{B}$. This is probably due to the different types of conventional therapeutics used in the different $\mathrm{BC}$ subtypes. In fact, chemotherapy (by further enhancing the expression of NK-activating ligands or reducing the expression of NK-inhibitory ligands on tumor cells) [151] and HER2-targeted therapy (by Trastuzumab-induced NK cell-based antibody-dependent cell-mediated cytotoxicity, i.e. ADCC) [152] were shown to increase cancer cell sensitivity to NK-mediated cytotoxicity which could act synergistically with the basal high expression of NKactivating ligands in basal-like and/or HER2-positive BCs. In contrast, tamoxifen, which is widely used in endocrine therapy for ER-positive (luminal A and B) BCs, was shown to inhibit NK-mediated BC cell death by inducing the expression of the granzyme B inhibitor (serpentinB9/ proteinase inhibitor 9), making these cells less responsive to NK despite the high expression of NK-activating ligands on their surface [153]. Furthermore, we could observe that the favorable prognostic influence of NKactivating ligands was significantly higher in lymph node positive and grade III BCs than in lymph node negative and lower grades BCs. This could be the consequence of a higher NK cell infiltration of lymph node positive and grade III BCs than in lymph node negative and lower grades BCs $[154,155]$. Thus, therapeutic approaches that can harness the cytotoxic potential of these lymphocytes might improve tumor management and survival in $\mathrm{BC}$ patients with lymph node involvement and/or grade III tumors that are; therefore, initially classed as having a poor prognosis.

In $\mathrm{BC}, \mathrm{NK}$ cell-based immunotherapy can have four main approaches [24]: 1) direct administration of these immune cells genetically modified and/or stimulated ex vivo. 2) administration of drugs, mainly cytokines, to stimulate NK cells in patients themselves. 3) targeting therapies with monoclonal antibodies (such as trastuzumab for HER2-positive breast cancer that triggers NK cellmediated ADCC. 4) use of immunomodulatory drugs such as TGF- $\beta 1$ or TGF- $\beta 1$ receptors inhibitors or blocking antibodies for NK-inhibitory receptors.
An increasing number of research studies trying to harness NK cell function against cancer cells were recently performed [24, 31, 32, 156, 157]. However, to date, in contrast to other types of cancer such as leukemia, neuroblastoma and glioblastoma, clinical trials using NK cell-based immunotherapy in $\mathrm{BC}$ failed to improve clinical outcomes [24]. Therefore, in order to develop effective anti-BC immunotherapy approaches and benefit from the high anti-tumoral potential of NK cells and their safety towards healthy tissues, it's crucial to determine and consider predictive biomarkers for NK-therapy responsiveness in $\mathrm{BC}$ patients.

In conclusion, in $\mathrm{BC}$, all $\mathrm{NK}$ receptor ligands were found to be of valuable potential prognostic biomarkers, that can or cannot be affected by the different $\mathrm{BC}$ subtypes or clinicopathological features depending on the individual ligand considered. The favorable prognostic influence of NK-activating ligands' upregulation, as a whole, was mainly significantly associated with HER2-positive and basal-like subtypes, lymph node positive phenotype and high-grade tumors. Furthermore, we identified two groups of $\mathrm{BC}$ patients with specific expressions of NK-activating ligands as potential candidates for NK-based therapy such as adoptive transfer of NK cells expressing receptors for these ligands. Those include patients with tumors whose NK-activating ligand is associated with higher RFS but no effect or worse OS as well as those with tumors whose NK-activating ligand is associated with worse RFS and/or OS. In addition to the high expression of the specific NKactivating ligand, these tumors of worse prognosis would be more likely to express low levels of NK-inhibitory ligands; thus, reducing the inhibitory signals for NK cell activation and enhancing their cytotoxic potential towards tumor cells. These tumor characteristics might increase the chances for successful NK-based immunotherapy in BC patients by eliminating residual tumor cells, preventing relapse and improving patient survival; thus highlighting the importance of further exploration of the prognostic and therapeutic implications of NK cells in $\mathrm{BC}$ in both research and clinical settings.

\section{MATERIALS AND METHODS}

\section{Identification of the NK-regulatory ligands for NK receptors by literature screening}

NK-regulatory receptors (expressed on NK cells) and their respective ligands (expressed on target cells) discovered to date, in humans, were identified by systematic literature screening in Pubmed. First, the keywords "NK" or "natural killer" and "receptor" were used to identify the potential NK receptors and ligands. Then, further literature search was performed, using the keywords "NK" or "natural killer" and "potential NK receptor name" and "potential ligand name" to select all ligands for which articles containing original research data confirming both their interaction with the NK receptor 
and their regulatory effect on NK activity and cytotoxicity towards the target cell. The exclusion criteria are the ligands that would have been found to bind specific NK receptors without confirmation of their regulatory effect on NK cell activity towards the target cells because these ligands might interfere with the overall conclusions of the study independently of the potential role of NK activity. The selected NK-regulatory ligands for NK receptors are presented in Table 1 and grouped into NK-activating, NK-inhibitory, or NK-activating and inhibitory ligands depending on the biological effect of their interaction with their receptors on NK cells (i.e. activation or inhibition of NK cytotoxic activity towards target cells).

\section{Analysis of the prognostic values of individual NK receptor ligands in $B C$ patients by using the KM plotter}

The correlation between $\mathrm{NK}$ receptor ligand members' mRNA expression and BC patient survival (RFS and OS) was analyzed by KM plotter platform. The analysis included 3955 BC patients for RFS and 1402 BC patients for OS. The BC patients were followed up for 20 years. The prognostic value of each ligand was evaluated either on all the BC tumors or by using several clinical $\mathrm{BC}$ criteria and classifications including intrinsic subtypes (luminal A, luminal B, HER2-positive and basal-like) and clinicopathological features (lymph node status, tumor grade, and p53 status). Briefly, individual members of the NK receptor ligands were entered by using their gene symbol into the KM plotter platform. The probe set with the estimated excellent quality (green) was used (the probe set ID for each ligand is indicated in Table 1). "Auto select best cutoff" was chosen in the analysis [158]. Different clinical parameters were selected. Thus, BC samples were split into high and low expression groups according to the cutoff value and the two patient cohorts were compared by Kaplan-Meier survival plots. The hazard ratio (HR) with $95 \%$ confidence intervals (CI) and $\log$ rank $P$ value were calculated then were adjusted using false discovery rate (FDR) for multiple testing correction. All $p$ values indicated in the manuscript are FDR-adjusted. $\mathrm{HR}<1$ implies better survival for high expression group, HR $>1$ implies worse survival for high expression group, and HR $=1$ implies no effect of ligand mRNA level on survival. The data is considered to be statistically significant when FDR-adjusted $p$ value $<0.05$.

\section{Abbreviations}

$\mathrm{BC}$ : breast cancer; $\mathrm{CI}$ : confidence interval; FDR: false discovery rate; EGA: European genome-phenome archive; ER: estrogen receptor; GEO: gene expression omnibus; HER2: human epidermal growth factor receptor 2; HR: hazard ratio; KM: Kaplan-Meier; NK: natural killer; OS: overall survival; PR: progesterone receptor; RFS: relapse-free survival; TCGA: the cancer genome atlas.

\section{Author contributions}

Study design and coordination: MK. Literature search: AA, GT and MK. Data extraction: AA, RH and MK. Data analysis and interpretation: AA and MK. Statistical analysis: MS. Manuscript drafting: AA. Manuscript editing and revision: MK.

\section{CONFLICTS OF INTEREST}

The authors declare that they have no competing interests.

\section{FUNDING}

This work was funded by QBRI, HBKU, Qatar Foundation.

\section{REFERENCES}

1. Duffy MJ, Harbeck N, Nap M, Molina R, Nicolini A, Senkus E, Cardoso F. Clinical use of biomarkers in breast cancer: Updated guidelines from the European Group on Tumor Markers (EGTM). Eur J Cancer. 2017; 75:284-98. https://doi.org/10.1016/j.ejca.2017.01.017.

2. Nicolini A, Ferrari P, Duffy MJ. Prognostic and predictive biomarkers in breast cancer: Past, present and future. Semin Cancer Biol. 2017 Sep 4. [Epub ahead of print]. https://doi. org/10.1016/j.semcancer.2017.08.010.

3. Senkus E, Kyriakides S, Ohno S, Penault-Llorca F, Poortmans P, Rutgers E, Zackrisson S, Cardoso F; ESMO Guidelines Committee. Primary breast cancer: ESMO Clinical Practice Guidelines for diagnosis, treatment and follow-up. Ann Oncol. 2015; 26:v8-30. https://doi.org/10.1093/annonc/mdv298.

4. Weigel MT, Dowsett M. Current and emerging biomarkers in breast cancer: prognosis and prediction. Endocr Relat Cancer. 2010; 17:R245-62. https://doi.org/10.1677/ ERC-10-0136.

5. Burstein HJ, Cirrincione CT, Barry WT, Chew HK, Tolaney SM, Lake DE, Ma C, Blackwell KL, Winer EP, Hudis CA. Endocrine therapy with or without inhibition of epidermal growth factor receptor and human epidermal growth factor receptor 2: a randomized, double-blind, placebo-controlled phase III trial of fulvestrant with or without lapatinib for postmenopausal women with hormone receptor-positive advanced breast cancer-CALGB 40302 (Alliance). J Clin Oncol. 2014; 32:3959-66. https://doi.org/10.1200/ JCO.2014.56.7941.

6. Eroglu Z, Tagawa T, Somlo G. Human epidermal growth factor receptor family-targeted therapies in the treatment of HER2-overexpressing breast cancer. 
Oncologist. 2014; 19:135-50. https://doi.org/10.1634/ theoncologist.2013-0283.

7. Colleoni M, Montagna E. Neoadjuvant therapy for ER-positive breast cancers. Ann Oncol. 2012; 23:x243-8. https://doi.org/10.1093/annonc/mds305.

8. Davies C, Pan H, Godwin J, Gray R, Arriagada R, Raina V, Abraham M, Medeiros Alencar VH, Badran A, Bonfill X, Bradbury J, Clarke M, Collins R, et al. Long-term effects of continuing adjuvant tamoxifen to 10 years versus stopping at 5 years after diagnosis of oestrogen receptor-positive breast cancer: ATLAS, a randomised trial. Lancet. 2013; 381:805-16. https://doi.org/10.1016/ S0140-6736(12)61963-1.

9. McGuire WL, Chamness GC, Costlow ME, Richert NJ. Steroids and human breast cancer. J Steroid Biochem. 1975; 6:723-7.

10. Ravdin PM, Green S, Dorr TM, McGuire WL, Fabian C, Pugh RP, Carter RD, Rivkin SE, Borst JR, Belt RJ. Prognostic significance of progesterone receptor levels in estrogen receptor-positive patients with metastatic breast cancer treated with tamoxifen: results of a prospective Southwest Oncology Group study. J Clin Oncol. 1992; 10:1284-91. https://doi.org/10.1200/JCO.1992.10.8.1284.

11. Rugo HS, Rumble RB, Macrae E, Barton DL, Connolly HK, Dickler MN, Fallowfield L, Fowble B, Ingle JN, Jahanzeb M, Johnston SR, Korde LA, Khatcheressian JL, et al. Endocrine Therapy for Hormone Receptor-Positive Metastatic Breast Cancer: American Society of Clinical Oncology Guideline. J Clin Oncol. 2016; 34:3069-103. https://doi.org/10.1200/JCO.2016.67.1487.

12. Vallejos CS, Gomez HL, Cruz WR, Pinto JA, Dyer RR, Velarde R, Suazo JF, Neciosup SP, Leon M, de la Cruz MA, Vigil CE. Breast cancer classification according to immunohistochemistry markers: subtypes and association with clinicopathologic variables in a peruvian hospital database. Clin Breast Cancer. 2010; 10:294-300. https:// doi.org/10.3816/CBC.2010.n.038.

13. Ferlay J, Steliarova-Foucher E, Lortet-Tieulent J, Rosso S, Coebergh JW, Comber H, Forman D, Bray F. Cancer incidence and mortality patterns in Europe: estimates for 40 countries in 2012. Eur J Cancer. 2013; 49:1374-403. https:// doi.org/10.1016/j.ejca.2012.12.027.

14. Dunn GP, Old LJ, Schreiber RD. The immunobiology of cancer immunosurveillance and immunoediting. Immunity. 2004; 21:137-48. https://doi.org/10.1016/j. immuni.2004.07.017.

15. Mlecnik B, Bindea G, Pages F, Galon J. Tumor immunosurveillance in human cancers. Cancer Metastasis Rev. 2011; 30:5-12. https://doi.org/10.1007/ s10555-011-9270-7.

16. Senovilla L, Vitale I, Martins I, Tailler M, Pailleret C, Michaud M, Galluzzi L, Adjemian S, Kepp O, NisoSantano M, Shen S, Marino G, Criollo A, et al. An immunosurveillance mechanism controls cancer cell ploidy.
Science. 2012; 337:1678-84. https://doi.org/10.1126/ science. 1224922 .

17. Vesely MD, Kershaw MH, Schreiber RD, Smyth MJ. Natural innate and adaptive immunity to cancer. Annu Rev Immunol. 2011; 29:235-71. https://doi.org/10.1146/ annurev-immunol-031210-101324.

18. Yaguchi T, Kawakami Y. Cancer-induced heterogeneous immunosuppressive tumor microenvironments and their personalized modulation. Int Immunol. 2016; 28:393-9. https://doi.org/10.1093/intimm/dxw030.

19. Beatty GL, Gladney WL. Immune escape mechanisms as a guide for cancer immunotherapy. Clin Cancer Res. 2015; 21:687-92. https://doi.org/10.1158/1078-0432. CCR-14-1860.

20. Papaioannou NE, Beniata OV, Vitsos P, Tsitsilonis O, Samara P. Harnessing the immune system to improve cancer therapy. Ann Transl Med. 2016; 4:261. https://doi. org/10.21037/atm.2016.04.01.

21. Bryceson YT, March ME, Ljunggren HG, Long EO. Activation, coactivation, and costimulation of resting human natural killer cells. Immunol Rev. 2006; 214:73-91. https://doi.org/10.1111/j.1600-065X.2006.00457.x.

22. Dewan MZ, Terunuma H, Takada M, Tanaka Y, Abe H, Sata T, Toi M, Yamamoto N. Role of natural killer cells in hormone-independent rapid tumor formation and spontaneous metastasis of breast cancer cells in vivo. Breast Cancer Res Treat. 2007; 104:267-75. https://doi. org/10.1007/s10549-006-9416-4.

23. Topham NJ, Hewitt EW. Natural killer cell cytotoxicity: how do they pull the trigger? Immunology. 2009; 128:7-15. https://doi.org/10.1111/j.1365-2567.2009.03123.x.

24. Guillerey C, Huntington ND, Smyth MJ. Targeting natural killer cells in cancer immunotherapy. Nat Immunol. 2016; 17:1025-36. https://doi.org/10.1038/ni.3518.

25. Carey LA. Breast cancer: HER2--a good addiction. Nat Rev Clin Oncol. 2012; 9:196-7. https://doi.org/10.1038/ nrclinonc.2012.36.

26. de Kruijf EM, Sajet A, van Nes JG, Putter H, Smit VT, Eagle RA, Jafferji I, Trowsdale J, Liefers GJ, van de Velde CJ, Kuppen PJ. NKG2D ligand tumor expression and association with clinical outcome in early breast cancer patients: an observational study. BMC Cancer. 2012; 12:24. https://doi.org/10.1186/1471-2407-12-24.

27. Dewan MZ, Takada M, Terunuma H, Deng X, Ahmed S, Yamamoto N, Toi M. Natural killer activity of peripheralblood mononuclear cells in breast cancer patients. Biomed Pharmacother. 2009; 63:703-6. https://doi.org/10.1016/j. biopha.2009.02.003.

28. Dewan MZ, Terunuma H, Ahmed S, Ohba K, Takada M, Tanaka Y, Toi M, Yamamoto N. Natural killer cells in breast cancer cell growth and metastasis in SCID mice. Biomed Pharmacother. 2005; 59 Suppl 2: S375-9.

29. Finak G, Bertos N, Pepin F, Sadekova S, Souleimanova M, Zhao H, Chen H, Omeroglu G, Meterissian S, Omeroglu 
A, Hallett M, Park M. Stromal gene expression predicts clinical outcome in breast cancer. Nat Med. 2008; 14:518 27. https://doi.org/10.1038/nm1764.

30. Garner WL, Minton JP, James AG, Hoffmann CC. Human breast cancer and impaired NK cell function. J Surg Oncol. 1983; 24:64-6.

31. Mamessier E, Sylvain A, Bertucci F, Castellano R, Finetti P, Houvenaeghel G, Charaffe-Jaufret E, Birnbaum D, Moretta A, Olive D. Human breast tumor cells induce self-tolerance mechanisms to avoid NKG2D-mediated and DNAMmediated NK cell recognition. Cancer Res. 2011; 71:662132. https://doi.org/10.1158/0008-5472.CAN-11-0792.

32. Mamessier E, Sylvain A, Thibult ML, Houvenaeghel G, Jacquemier J, Castellano R, Goncalves A, Andre P, Romagne F, Thibault G, Viens P, Birnbaum D, Bertucci F, et al. Human breast cancer cells enhance self tolerance by promoting evasion from NK cell antitumor immunity. J Clin Invest. 2011; 121:3609-22. https://doi.org/10.1172/ JCI45816.

33. Tian W, Wang L, Yuan L, Duan W, Zhao W, Wang S, Zhang Q. A prognostic risk model for patients with triple negative breast cancer based on stromal natural killer cells, tumorassociated macrophages and growth-arrest specific protein 6. Cancer Sci. 2016; 107:882-9. https://doi.org/10.1111/ cas. 12964 .

34. Lanier LL. NK cell recognition. Annu Rev Immunol. 2005; 23:225-74. https://doi.org/10.1146/annurev. immunol.23.021704.115526.

35. Pegram HJ, Andrews DM, Smyth MJ, Darcy PK, Kershaw MH. Activating and inhibitory receptors of natural killer cells. Immunol Cell Biol. 2011; 89:216-24. https://doi. org/10.1038/icb.2010.78.

36. Campbell KS, Hasegawa J. Natural killer cell biology: an update and future directions. J Allergy Clin Immunol. 2013; 132:536-44. https://doi.org/10.1016/j.jaci.2013.07.006.

37. Karre K. Immunology. A perfect mismatch. Science. 2002; 295:2029-31. https://doi.org/10.1126/science.1070538.

38. Matzinger P. The danger model: a renewed sense of self. Science. 2002; 296:301-5. https://doi.org/10.1126/ science. 1071059.

39. Bradley M, Zeytun A, Rafi-Janajreh A, Nagarkatti PS, Nagarkatti M. Role of spontaneous and interleukin-2-induced natural killer cell activity in the cytotoxicity and rejection of Fas + and Fas- tumor cells. Blood. 1998; 92:4248-55.

40. Caligiuri MA. Human natural killer cells. Blood. 2008; 112:461-9. https://doi.org/10.1182/blood-2007-09-077438.

41. Clayton A, Mitchell JP, Court J, Linnane S, Mason MD, Tabi Z. Human tumor-derived exosomes down-modulate NKG2D expression. J Immunol. 2008; 180:7249-58.

42. Clayton A, Tabi Z. Exosomes and the MICA-NKG2D system in cancer. Blood Cells Mol Dis. 2005; 34:206-13. https://doi.org/10.1016/j.bcmd.2005.03.003.

43. Hedlund M, Nagaeva O, Kargl D, Baranov V, MinchevaNilsson L. Thermal- and oxidative stress causes enhanced release of NKG2D ligand-bearing immunosuppressive exosomes in leukemia/lymphoma T and B cells. PLoS One. 2011; 6:e16899. https://doi.org/10.1371/journal. pone. 0016899 .

44. Lanier LL. NKG2D Receptor and Its Ligands in Host Defense. Cancer Immunol Res. 2015; 3:575-82. https://doi. org/10.1158/2326-6066.CIR-15-0098.

45. Pogge von Strandmann E, Shatnyeva O, Hansen HP. NKp30 and its ligands: emerging players in tumor immune evasion from natural killer cells. Ann Transl Med. 2015; 3:314. https://doi.org/10.3978/j.issn.2305-5839.2015.09.08.

46. Raulet DH, Gasser S, Gowen BG, Deng W, Jung H. Regulation of ligands for the NKG2D activating receptor. Annu Rev Immunol. 2013; 31:413-41. https://doi. org/10.1146/annurev-immunol-032712-095951.

47. Schlecker E, Fiegler N, Arnold A, Altevogt P, Rose-John S, Moldenhauer G, Sucker A, Paschen A, von Strandmann EP, Textor S, Cerwenka A. Metalloprotease-mediated tumor cell shedding of B7-H6, the ligand of the natural killer cellactivating receptor NKp30. Cancer Res. 2014; 74:3429-40. https://doi.org/10.1158/0008-5472.CAN-13-3017.

48. Shen J, Pan J, Du C, Si W, Yao M, Xu L, Zheng H, Xu M, Chen D, Wang S, Fu P, Fan W. Silencing NKG2D ligandtargeting miRNAs enhances natural killer cell-mediated cytotoxicity in breast cancer. Cell Death Dis. 2017; 8:e2740. https://doi.org/10.1038/cddis.2017.158.

49. Gyorffy B, Lanczky A, Eklund AC, Denkert C, Budczies J, Li Q, Szallasi Z. An online survival analysis tool to rapidly assess the effect of 22,277 genes on breast cancer prognosis using microarray data of 1,809 patients. Breast Cancer Res Treat. 2010; 123:725-31. https://doi.org/10.1007/ s10549-009-0674-9.

50. Peng WX, Huang JG, Yang L, Gong AH, Mo YY. LincRoR promotes MAPK/ERK signaling and confers estrogenindependent growth of breast cancer. Mol Cancer. 2017; 16:161. https://doi.org/10.1186/s12943-017-0727-3.

51. Sun X, Clermont PL, Jiao W, Helgason CD, Gout PW, Wang Y, Qu S. Elevated expression of the centromere protein-A(CENP-A)-encoding gene as a prognostic and predictive biomarker in human cancers. Int J Cancer. 2016; 139:899-907. https://doi.org/10.1002/ijc.30133.

52. Tilghman SL, Townley I, Zhong Q, Carriere PP, Zou J, Llopis SD, Preyan LC, Williams CC, Skripnikova E, Bratton MR, Zhang Q, Wang G. Proteomic signatures of acquired letrozole resistance in breast cancer: suppressed estrogen signaling and increased cell motility and invasiveness. Mol Cell Proteomics. 2013; 12:2440-55. https://doi.org/10.1074/mcp.M112.023861.

53. Zhang S, Wang Z, Liu W, Lei R, Shan J, Li L, Wang X. Distinct prognostic values of S100 mRNA expression in breast cancer. Sci Rep. 2017; 7:39786. https://doi. org/10.1038/srep39786.

54. Zhou C, Zhong Q, Rhodes LV, Townley I, Bratton MR, Zhang Q, Martin EC, Elliott S, Collins-Burow BM, Burow 
ME, Wang G. Proteomic analysis of acquired tamoxifen resistance in MCF-7 cells reveals expression signatures associated with enhanced migration. Breast Cancer Res. 2012; 14:R45. https://doi.org/10.1186/bcr3144.

55. Dotsch MM, Kloten V, Schlensog M, Heide $T$, Braunschweig T, Veeck J, Petersen I, Knuchel R, Dahl E. Low expression of ITIH5 in adenocarcinoma of the lung is associated with unfavorable patients' outcome. Epigenetics. 2015; 10:903-12. https://doi.org/10.1080/15592294.2015.1 078049 .

56. Ortega CE, Seidner Y, Dominguez I. Mining CK2 in cancer. PLoS One. 2014; 9:e115609. https://doi.org/10.1371/ journal.pone.0115609.

57. Xiong J, Zhang X, Chen X, Wei Y, Lu DG, Han YW, Xu $\mathrm{J}, \mathrm{Yu} \mathrm{D}$. Prognostic roles of mRNA expression of notch receptors in non-small cell lung cancer. Oncotarget. 2017; 8:13157-65. https://doi.org/10.18632/oncotarget.14483.

58. Chen C, Wang X, Huang S, Wang L, Han L, Yu S. Prognostic roles of Notch receptor mRNA expression in human ovarian cancer. Oncotarget. 2017; 8:32731-40. https://doi.org/10.18632/oncotarget.16387.

59. Ocana A, Perez-Pena J, Alcaraz-Sanabria A, SanchezCorrales V, Nieto-Jimenez C, Templeton AJ, Seruga B, Pandiella A, Amir E. In silico analyses identify gene-sets, associated with clinical outcome in ovarian cancer: role of mitotic kinases. Oncotarget. 2016; 7:22865-72. https://doi. org/10.18632/oncotarget.8118.

60. Zhou X, Teng L, Wang M. Distinct prognostic values of four-Notch-receptor mRNA expression in ovarian cancer. Tumour Biol. 2016; 37:6979-85. https://doi.org/10.1007/ s13277-015-4594-5.

61. Shen JX, Liu J, Li GW, Huang YT, Wu HT. Mining distinct aldehyde dehydrogenase 1 (ALDH1) isoenzymes in gastric cancer. Oncotarget. 2016; 7:25340-9. https://doi. org/10.18632/oncotarget.8294.

62. Wu X, Liu W, Tang D, Xiao H, Wu Z, Chen C, Yao X, Liu F, Li G. Prognostic values of four Notch receptor mRNA expression in gastric cancer. Sci Rep. 2016; 6:28044. https://doi.org/10.1038/srep28044.

63. Xia P, Xu XY. Prognostic significance of CD44 in human colon cancer and gastric cancer: Evidence from bioinformatic analyses. Oncotarget. 2016; 7:45538-46. https://doi.org/10.18632/oncotarget.9998.

64. Al Sayed MF, Ruckstuhl CA, Hilmenyuk T, Claus C, Bourquin JP, Bornhauser BC, Radpour R, Riether C, Ochsenbein AF. CD70 reverse signaling enhances NK cell function and immunosurveillance in CD27-expressing B-cell malignancies. Blood. 2017; 130:297-309. https://doi. org/10.1182/blood-2016-12-756585.

65. Bloushtain N, Qimron U, Bar-Ilan A, Hershkovitz O, Gazit R, Fima E, Korc M, Vlodavsky I, Bovin NV, Porgador A. Membrane-associated heparan sulfate proteoglycans are involved in the recognition of cellular targets by NKp30 and NKp46. J Immunol. 2004; 173:2392-401.
66. Brandt CS, Baratin M, Yi EC, Kennedy J, Gao Z, Fox B, Haldeman B, Ostrander CD, Kaifu T, Chabannon C, Moretta A, West R, Xu W, et al. The B7 family member B7-H6 is a tumor cell ligand for the activating natural killer cell receptor NKp30 in humans. J Exp Med. 2009; 206:1495-503. https://doi.org/10.1084/jem.20090681.

67. Brown $\mathrm{MH}$, Boles $\mathrm{K}$, van der Merwe PA, Kumar V, Mathew PA, Barclay AN. 2B4, the natural killer and T cell immunoglobulin superfamily surface protein, is a ligand for CD48. J Exp Med. 1998; 188:2083-90.

68. Chambers BJ, Salcedo M, Ljunggren HG. Triggering of natural killer cells by the costimulatory molecule CD80 (B7-1). Immunity. 1996; 5:311-7.

69. Latchman Y, McKay PF, Reiser H. Identification of the 2B4 molecule as a counter-receptor for CD48. J Immunol. 1998; 161:5809-12.

70. Lee KM, Forman JP, McNerney ME, Stepp S, Kuppireddi S, Guzior D, Latchman YE, Sayegh MH, Yagita H, Park CK, Oh SB, Wulfing C, Schatzle J, et al. Requirement of homotypic NK-cell interactions through 2B4(CD244)/CD48 in the generation of NK effector functions. Blood. 2006; 107:3181-8. https://doi.org/10.1182/blood-2005-01-0185.

71. Luque I, Reyburn H, Strominger JL. Expression of the CD80 and CD86 molecules enhances cytotoxicity by human natural killer cells. Hum Immunol. 2000; 61:721-8.

72. Mizrahi S, Markel G, Porgador A, Bushkin Y, Mandelboim O. CD100 on NK cells enhance IFNgamma secretion and killing of target cells expressing CD72. PLoS One. 2007; 2:e818. https://doi.org/10.1371/journal.pone.0000818.

73. Pogge von Strandmann E, Simhadri VR, von Tresckow B, Sasse S, Reiners KS, Hansen HP, Rothe A, Boll B, Simhadri VL, Borchmann P, McKinnon PJ, Hallek M, Engert A. Human leukocyte antigen-B-associated transcript 3 is released from tumor cells and engages the NKp30 receptor on natural killer cells. Immunity. 2007; 27:965-74. https:// doi.org/10.1016/j.immuni.2007.10.010.

74. Takeda K, Oshima H, Hayakawa Y, Akiba H, Atsuta M, Kobata T, Kobayashi K, Ito M, Yagita H, Okumura K. CD27-mediated activation of murine NK cells. J Immunol. 2000; 164:1741-5.

75. Vivier E, Morin P, O'Brien C, Druker B, Schlossman SF, Anderson P. Tyrosine phosphorylation of the Fc gamma RIII(CD16): zeta complex in human natural killer cells. Induction by antibody-dependent cytotoxicity but not by natural killing. J Immunol. 1991; 146:206-10.

76. Welte S, Kuttruff S, Waldhauer I, Steinle A. Mutual activation of natural killer cells and monocytes mediated by NKp80-AICL interaction. Nat Immunol. 2006; 7:1334-42. https://doi.org/10.1038/ni1402.

77. Wilson JL, Charo J, Martin-Fontecha A, Dellabona P, Casorati G, Chambers BJ, Kiessling R, Bejarano MT, Ljunggren HG. NK cell triggering by the human costimulatory molecules CD80 and CD86. J Immunol. $1999 ; 163: 4207-12$. 
78. Bacon L, Eagle RA, Meyer M, Easom N, Young NT, Trowsdale J. Two human ULBP/RAET1 molecules with transmembrane regions are ligands for NKG2D. J Immunol. 2004; 173:1078-84.

79. Bauer S, Groh V, Wu J, Steinle A, Phillips JH, Lanier LL, Spies T. Activation of NK cells and T cells by NKG2D, a receptor for stress-inducible MICA. Science. 1999; 285:727-9.

80. Baychelier F, Sennepin A, Ermonval M, Dorgham K, Debre P, Vieillard V. Identification of a cellular ligand for the natural cytotoxicity receptor $\mathrm{NKp} 44$. Blood. 2013; 122:2935-42. https://doi.org/10.1182/ blood-2013-03-489054.

81. Boles KS, Barchet W, Diacovo T, Cella M, Colonna M. The tumor suppressor TSLC1/NECL-2 triggers NK-cell and CD8+ T-cell responses through the cell-surface receptor CRTAM. Blood. 2005; 106:779-86. https://doi.org/10.1182/ blood-2005-02-0817.

82. Chalupny NJ, Sutherland CL, Lawrence WA, Rein-Weston A, Cosman D. ULBP4 is a novel ligand for human NKG2D. Biochem Biophys Res Commun. 2003; 305:129-35.

83. Cosman D, Mullberg J, Sutherland CL, Chin W, Armitage R, Fanslow W, Kubin M, Chalupny NJ. ULBPs, novel MHC class I-related molecules, bind to CMV glycoprotein UL16 and stimulate NK cytotoxicity through the NKG2D receptor. Immunity. 2001; 14:123-33.

84. Eagle RA, Traherne JA, Hair JR, Jafferji I, Trowsdale J. ULBP6/RAET1L is an additional human NKG2D ligand. Eur J Immunol. 2009; 39:3207-16. https://doi.org/10.1002/ eji.200939502.

85. Flaig RM, Stark S, Watzl C. Cutting edge: NTB-A activates NK cells via homophilic interaction. J Immunol. 2004; 172:6524-7.

86. Fujisaki H, Kakuda H, Shimasaki N, Imai C, Ma J, Lockey T, Eldridge P, Leung WH, Campana D. Expansion of highly cytotoxic human natural killer cells for cancer cell therapy. Cancer Res. 2009; 69:4010-7. https://doi.org/10.1158/00085472.CAN-08-3712.

87. Garg A, Barnes PF, Porgador A, Roy S, Wu S, Nanda JS, Griffith DE, Girard WM, Rawal N, Shetty S, Vankayalapati R. Vimentin expressed on Mycobacterium tuberculosisinfected human monocytes is involved in binding to the NKp46 receptor. J Immunol. 2006; 177:6192-8.

88. Hecht ML, Rosental B, Horlacher T, Hershkovitz O, De Paz JL, Noti C, Schauer S, Porgador A, Seeberger PH. Natural cytotoxicity receptors NKp30, NKp44 and NKp46 bind to different heparan sulfate/heparin sequences. J Proteome Res. 2009; 8:712-20. https://doi.org/10.1021/pr800747c.

89. Kohrt HE, Houot R, Goldstein MJ, Weiskopf K, Alizadeh AA, Brody J, Muller A, Pachynski R, Czerwinski D, Coutre S, Chao MP, Chen L, Tedder TF, et al. CD137 stimulation enhances the antilymphoma activity of anti-CD20 antibodies. Blood. 2011; 117:2423-32. https:// doi.org/10.1182/blood-2010-08-301945
90. Kohrt HE, Houot R, Weiskopf K, Goldstein MJ, Scheeren F, Czerwinski D, Colevas AD, Weng WK, Clarke MF, Carlson RW, Stockdale FE, Mollick JA, Chen L, et al. Stimulation of natural killer cells with a CD137-specific antibody enhances trastuzumab efficacy in xenotransplant models of breast cancer. J Clin Invest. 2012; 122:1066-75. https://doi. org/10.1172/JCI61226.

91. Kumaresan PR, Lai WC, Chuang SS, Bennett M, Mathew PA. CS1, a novel member of the CD2 family, is homophilic and regulates NK cell function. Mol Immunol. 2002; 39:1-8.

92. Mandelboim O, Lieberman N, Lev M, Paul L, Arnon TI, Bushkin Y, Davis DM, Strominger JL, Yewdell JW, Porgador A. Recognition of haemagglutinins on virus-infected cells by NKp46 activates lysis by human NK cells. Nature. 2001; 409:1055-60. https://doi. org/10.1038/35059110.

93. Wang X, Lee DA, Wang Y, Wang L, Yao Y, Lin Z, Cheng J, Zhu S. Membrane-bound interleukin-21 and CD137 ligand induce functional human natural killer cells from peripheral blood mononuclear cells through STAT-3 activation. Clin Exp Immunol. 2013; 172:104-12. https://doi.org/10.1111/ cei.12034.

94. Arnon TI, Lev M, Katz G, Chernobrov Y, Porgador A, Mandelboim O. Recognition of viral hemagglutinins by NKp44 but not by NKp30. Eur J Immunol. 2001; 31:2680-9. https://doi. org/10.1002/1521-4141(200109)31:9\&\#60;2680::AIDIMMU2680\&\#62;3.0.CO;2-A.

95. Biassoni R, Pessino A, Malaspina A, Cantoni C, Bottino C, Sivori S, Moretta L, Moretta A. Role of amino acid position 70 in the binding affinity of p50.1 and p58.1 receptors for HLA-Cw4 molecules. Eur J Immunol. 1997; 27:3095-9. https://doi.org/10.1002/eji.1830271203.

96. Braud VM, Allan DS, O'Callaghan CA, Soderstrom K, D'Andrea A, Ogg GS, Lazetic S, Young NT, Bell JI, Phillips JH, Lanier LL, McMichael AJ. HLA-E binds to natural killer cell receptors CD94/NKG2A, B and C. Nature. 1998; 391:795-9. https://doi.org/10.1038/35869.

97. Campbell KS, Cella M, Carretero M, LopezBotet M, Colonna M. Signaling through human killer cell activating receptors triggers tyrosine phosphorylation of an associated protein complex. Eur J Immunol. 1998; 28:599-609. https://doi.org/10.1002/ (SICI)1521-4141(199802)28:02\&\#60;599::AIDIMMU599\&\#62;3.0.CO;2-F.

98. Carretero M, Cantoni C, Bellon T, Bottino C, Biassoni R, Rodriguez A, Perez-Villar JJ, Moretta L, Moretta A, LopezBotet M. The CD94 and NKG2-A C-type lectins covalently assemble to form a natural killer cell inhibitory receptor for HLA class I molecules. Eur J Immunol. 1997; 27:563-7. https://doi.org/10.1002/eji.1830270230.

99. Chan CJ, Martinet L, Gilfillan S, Souza-Fonseca-Guimaraes F, Chow MT, Town L, Ritchie DS, Colonna M, Andrews 
DM, Smyth MJ. The receptors CD96 and CD226 oppose each other in the regulation of natural killer cell functions. Nat Immunol. 2014; 15:431-8. https://doi.org/10.1038/ ni. 2850 .

100. Fan QR, Garboczi DN, Winter CC, Wagtmann N, Long EO, Wiley DC. Direct binding of a soluble natural killer cell inhibitory receptor to a soluble human leukocyte antigen-Cw4 class I major histocompatibility complex molecule. Proc Natl Acad Sci U S A. 1996; 93:7178-83.

101. Houchins JP, Lanier LL, Niemi EC, Phillips JH, Ryan JC. Natural killer cell cytolytic activity is inhibited by NKG2-A and activated by NKG2-C. J Immunol. 1997; 158:3603-9.

102. Kaiser BK, Barahmand-Pour F, Paulsene W, Medley S, Geraghty DE, Strong RK. Interactions between NKG2x immunoreceptors and HLA-E ligands display overlapping affinities and thermodynamics. J Immunol. 2005; 174:2878-84.

103. Katz G, Markel G, Mizrahi S, Arnon TI, Mandelboim O. Recognition of HLA-Cw4 but not HLA-Cw6 by the NK cell receptor killer cell Ig-like receptor two-domain short tail number 4. J Immunol. 2001; 166:7260-7.

104. Le Bouteiller P, Barakonyi A, Giustiniani J, Lenfant F, Marie-Cardine A, Aguerre-Girr M, Rabot M, Hilgert I, Mami-Chouaib F, Tabiasco J, Boumsell L, Bensussan A. Engagement of CD160 receptor by HLA-C is a triggering mechanism used by circulating natural killer (NK) cells to mediate cytotoxicity. Proc Natl Acad Sci U S A. 2002; 99:16963-8. https://doi.org/10.1073/pnas.012681099.

105. Le Drean E, Vely F, Olcese L, Cambiaggi A, Guia S, Krystal G, Gervois N, Moretta A, Jotereau F, Vivier E. Inhibition of antigen-induced $\mathrm{T}$ cell response and antibody-induced NK cell cytotoxicity by NKG2A: association of NKG2A with SHP-1 and SHP-2 protein-tyrosine phosphatases. Eur J Immunol. 1998; 28:264-76. https://doi.org/10.1002/ (SICI)1521-4141(199801)28:01\&\#60;264::AIDIMMU264\&\#62;3.0.CO;2-O.

106. Palmieri G, Tullio V, Zingoni A, Piccoli M, Frati L, LopezBotet M, Santoni A. CD94/NKG2-A inhibitory complex blocks CD16-triggered Syk and extracellular regulated kinase activation, leading to cytotoxic function of human NK cells. J Immunol. 1999; 162:7181-8.

107. van der Ploeg K, Chang C, Ivarsson MA, Moffett A, Wills MR, Trowsdale J. Modulation of Human Leukocyte Antigen-C by Human Cytomegalovirus Stimulates KIR2DS1 Recognition by Natural Killer Cells. Front Immunol. 2017; 8:298. https://doi.org/10.3389/ fimmu.2017.00298.

108. Wagtmann N, Rajagopalan S, Winter CC, Peruzzi M, Long EO. Killer cell inhibitory receptors specific for HLA-C and HLA-B identified by direct binding and by functional transfer. Immunity. 1995; 3:801-9.

109. Winter CC, Gumperz JE, Parham P, Long EO, Wagtmann N. Direct binding and functional transfer of NK cell inhibitory receptors reveal novel patterns of HLA-C allotype recognition. J Immunol. 1998; 161:571-7.
110. Aldemir H, Prod'homme V, Dumaurier MJ, Retiere C, Poupon G, Cazareth J, Bihl F, Braud VM. Cutting edge: lectin-like transcript 1 is a ligand for the CD161 receptor. J Immunol. 2005; 175:7791-5.

111. Arnon TI, Achdout H, Levi O, Markel G, Saleh N, Katz G, Gazit R, Gonen-Gross T, Hanna J, Nahari E, Porgador A, Honigman A, Plachter B, et al. Inhibition of the NKp30 activating receptor by pp65 of human cytomegalovirus. Nat Immunol. 2005; 6:515-23. https://doi.org/10.1038/ni1190.

112. Bottino C, Castriconi R, Pende D, Rivera P, Nanni M, Carnemolla B, Cantoni C, Grassi J, Marcenaro S, Reymond N, Vitale M, Moretta L, Lopez M, et al. Identification of PVR (CD155) and Nectin-2 (CD112) as cell surface ligands for the human DNAM-1 (CD226) activating molecule. J Exp Med. 2003; 198:557-67. https://doi.org/10.1084/ jem.20030788.

113. Colonna M, Navarro F, Bellon T, Llano M, Garcia P, Samaridis J, Angman L, Cella M, Lopez-Botet M. A common inhibitory receptor for major histocompatibility complex class I molecules on human lymphoid and myelomonocytic cells. J Exp Med. 1997; 186:1809-18.

114. Dohring C, Scheidegger D, Samaridis J, Cella M, Colonna M. A human killer inhibitory receptor specific for HLAA1,2. J Immunol. 1996; 156:3098-101.

115. Fuchs A, Cella M, Giurisato E, Shaw AS, Colonna M. Cutting edge: CD96 (tactile) promotes NK cell-target cell adhesion by interacting with the poliovirus receptor (CD155). J Immunol. 2004; 172:3994-8.

116. Hansasuta P, Dong T, Thananchai H, Weekes M, Willberg C, Aldemir H, Rowland-Jones S, Braud VM. Recognition of HLA-A3 and HLA-A11 by KIR3DL2 is peptide-specific. Eur J Immunol. 2004; 34:1673-9. https://doi.org/10.1002/ eji.200425089.

117. Lebbink RJ, de Ruiter T, Adelmeijer J, Brenkman AB, van Helvoort JM, Koch M, Farndale RW, Lisman T, Sonnenberg A, Lenting PJ, Meyaard L. Collagens are functional, high affinity ligands for the inhibitory immune receptor LAIR1. J Exp Med. 2006; 203:1419-25. https://doi.org/10.1084/ jem.20052554.

118. Markel G, Wolf D, Hanna J, Gazit R, Goldman-Wohl D, Lavy Y, Yagel S, Mandelboim O. Pivotal role of CEACAM1 protein in the inhibition of activated decidual lymphocyte functions. J Clin Invest. 2002; 110:943-53. https://doi. org/10.1172/JCI15643.

119. Merkt W, Urlaub D, Meinke S, Kammerer R, Watzl C. Inhibition of NKp30- and 2B4-mediated NK cell activation by evolutionary different human and bovine CEACAM1 receptors. Eur J Immunol. 2015; 45:2134-42. https://doi. org/10.1002/eji.201445151.

120. Meyaard L, Adema GJ, Chang C, Woollatt E, Sutherland GR, Lanier LL, Phillips JH. LAIR-1, a novel inhibitory receptor expressed on human mononuclear leukocytes. Immunity. 1997; 7:283-90.

121. Pende D, Biassoni R, Cantoni C, Verdiani S, Falco M, di Donato C, Accame L, Bottino C, Moretta A, Moretta L. The 
natural killer cell receptor specific for HLA-A allotypes: a novel member of the $\mathrm{p} 58 / \mathrm{p} 70$ family of inhibitory receptors that is characterized by three immunoglobulin-like domains and is expressed as a $140-\mathrm{kD}$ disulphide-linked dimer. J Exp Med. 1996; 184:505-18.

122. Rosen DB, Bettadapura J, Alsharifi M, Mathew PA, Warren HS, Lanier LL. Cutting edge: lectin-like transcript-1 is a ligand for the inhibitory human NKR-P1A receptor. J Immunol. 2005; 175:7796-9.

123. Seth S, Maier MK, Qiu Q, Ravens I, Kremmer E, Forster $\mathrm{R}$, Bernhardt G. The murine pan T cell marker CD96 is an adhesion receptor for CD155 and nectin-1. Biochem Biophys Res Commun. 2007; 364:959-65. https://doi. org/10.1016/j.bbrc.2007.10.102.

124. Stanietsky N, Simic H, Arapovic J, Toporik A, Levy O, Novik A, Levine Z, Beiman M, Dassa L, Achdout H, SternGinossar N, Tsukerman P, Jonjic S, et al. The interaction of TIGIT with PVR and PVRL2 inhibits human NK cell cytotoxicity. Proc Natl Acad Sci U S A. 2009; 106:1785863. https://doi.org/10.1073/pnas.0903474106.

125. Xu F, Sunderland A, Zhou Y, Schulick RD, Edil BH, Zhu Y. Blockade of CD112R and TIGIT signaling sensitizes human natural killer cell functions. Cancer Immunol Immunother. 2017; 66:1367-75. https://doi.org/10.1007/ s00262-017-2031-x.

126. Zhang XH, Lian XD, Dai ZX, Zheng HY, Chen X, Zheng YT. alpha3-Deletion Isoform of HLA-A11 Modulates Cytotoxicity of NK Cells: Correlations with HIV-1 Infection of Cells. J Immunol. 2017; 199:2030-42. https:// doi.org/10.4049/jimmunol.1602183.

127. Benson DM Jr, Bakan CE, Mishra A, Hofmeister CC, Efebera Y, Becknell B, Baiocchi RA, Zhang J, Yu J, Smith MK, Greenfield CN, Porcu P, Devine SM, et al. The PD-1/ PD-L1 axis modulates the natural killer cell versus multiple myeloma effect: a therapeutic target for CT-011, a novel monoclonal anti-PD-1 antibody. Blood. 2010; 116:2286-94. https://doi.org/10.1182/blood-2010-02-271874.

128. Gumperz JE, Litwin V, Phillips JH, Lanier LL, Parham P. The Bw4 public epitope of HLA-B molecules confers reactivity with natural killer cell clones that express NKB1, a putative HLA receptor. J Exp Med. 1995; 181:1133-44.

129. Latchman Y, Wood CR, Chernova T, Chaudhary D, Borde M, Chernova I, Iwai Y, Long AJ, Brown JA, Nunes R, Greenfield EA, Bourque K, Boussiotis VA, et al. PD-L2 is a second ligand for PD-1 and inhibits T cell activation. Nat Immunol. 2001; 2:261-8. https://doi.org/10.1038/85330.

130. Liu Y, Cheng Y, Xu Y, Wang Z, Du X, Li C, Peng J, Gao L, Liang X, Ma C. Increased expression of programmed cell death protein 1 on NK cells inhibits NK-cell-mediated anti-tumor function and indicates poor prognosis in digestive cancers. Oncogene. 2017; 36:6143-53. https:// doi.org/10.1038/onc.2017.209.

131. Du D, Katsuno Y, Meyer D, Budi EH, Chen SH, Koeppen H, Wang H, Akhurst RJ, Derynck R. Smad3-mediated recruitment of the methyltransferase SETDB1/ESET controls Snaill expression and epithelial-mesenchymal transition. EMBO Rep. 2018; 19:135-55. https://doi. org/10.15252/embr.201744250.

132. Rolle A, Halenius A, Ewen EM, Cerwenka A, Hengel H, Momburg F. CD2-CD58 interactions are pivotal for the activation and function of adaptive natural killer cells in human cytomegalovirus infection. Eur J Immunol. 2016; 46:2420-5. https://doi.org/10.1002/eji.201646492.

133. Zheng X, Wang Y, Wei H, Sun R, Tian Z. LFA-1 and CD2 synergize for the Erk1/2 activation in the Natural Killer (NK) cell immunological synapse. J Biol Chem. 2009; 284:21280-7. https://doi.org/10.1074/jbc.M807053200.

134. Saez RA, McGuire WL, Clark GM. Prognostic factors in breast cancer. Semin Surg Oncol. 1989; 5:102-10.

135. Gasco M, Shami S, Crook T. The p53 pathway in breast cancer. Breast Cancer Res. 2002; 4:70-6.

136. Pharoah PD, Day NE, Caldas C. Somatic mutations in the p53 gene and prognosis in breast cancer: a meta-analysis. Br J Cancer. 1999; 80:1968-73. https://doi.org/10.1038/ sj.bjc.6690628.

137. Mamessier E, Bourgin C, Olive D. When breast cancer cells start to fend the educational process of NK cells off. Oncoimmunology. 2013; 2:e26688. https://doi.org/10.4161/ onci.26688.

138. Yong ST, Wang XF. A novel, non-apoptotic role for Scythe/BAT3: a functional switch between the pro- and anti-proliferative roles of $\mathrm{p} 21$ during the cell cycle. PLoS One. 2012; 7:e38085. https://doi.org/10.1371/journal. pone. 0038085 .

139. Wu W, Song W, Li S, Ouyang S, Fok KL, Diao R, Miao S, Chan HC, Wang L. Regulation of apoptosis by Bat3enhanced YWK-II/APLP2 protein stability. J Cell Sci. 2012; 125:4219-29. https://doi.org/10.1242/jcs.086553.

140. Xu S, Wen Z, Jiang Q, Zhu L, Feng S, Zhao Y, Wu J, Dong Q, Mao J, Zhu Y. CD58, a novel surface marker, promotes self-renewal of tumor-initiating cells in colorectal cancer. Oncogene. 2015; 34:1520-31. https://doi.org/10.1038/ onc. 2014.95 .

141. Garrido F, Aptsiauri N, Doorduijn EM, Garcia Lora AM, van Hall T. The urgent need to recover MHC class I in cancers for effective immunotherapy. Curr Opin Immunol. 2016; 39:44-51. https://doi.org/10.1016/j.coi.2015.12.007.

142. Kaneko K, Ishigami S, Kijima Y, Funasako Y, Hirata M, Okumura H, Shinchi H, Koriyama C, Ueno S, Yoshinaka H, Natsugoe S. Clinical implication of HLA class I expression in breast cancer. BMC Cancer. 2011; 11:454. https://doi. org/10.1186/1471-2407-11-454.

143. Izzi L, Turbide C, Houde C, Kunath T, Beauchemin N. cisDeterminants in the cytoplasmic domain of CEACAM1 responsible for its tumor inhibitory function. Oncogene. 1999; 18:5563-72. https://doi.org/10.1038/sj.onc.1202935.

144. Nittka S, Gunther J, Ebisch C, Erbersdobler A, Neumaier M. The human tumor suppressor CEACAM1 modulates apoptosis and is implicated in early colorectal 
tumorigenesis. Oncogene. 2004; 23:9306-13. https://doi. org/10.1038/sj.onc. 1208259.

145. Dong Y, Sun Q, Zhang X. PD-1 and its ligands are important immune checkpoints in cancer. Oncotarget. 2017; 8:217186. https://doi.org/10.18632/oncotarget.13895.

146. Baptista MZ, Sarian LO, Derchain SF, Pinto GA, Vassallo J. Prognostic significance of PD-L1 and PD-L2 in breast cancer. Hum Pathol. 2016; 47:78-84. https://doi. org/10.1016/j.humpath.2015.09.006.

147. Schalper KA, Velcheti V, Carvajal D, Wimberly H, Brown J, Pusztai L, Rimm DL. In situ tumor PD-L1 mRNA expression is associated with increased TILs and better outcome in breast carcinomas. Clin Cancer Res. 2014; 20:2773-82. https://doi.org/10.1158/1078-0432. CCR-13-2702.

148. Kinter AL, Godbout EJ, McNally JP, Sereti I, Roby GA, O'Shea MA, Fauci AS. The common gamma-chain cytokines IL-2, IL-7, IL-15, and IL-21 induce the expression of programmed death-1 and its ligands. J Immunol. 2008; 181:6738-46.

149. Mittendorf EA, Philips AV, Meric-Bernstam F, Qiao N, Wu Y, Harrington S, Su X, Wang Y, Gonzalez-Angulo AM, Akcakanat A, Chawla A, Curran M, Hwu P, et al. PD-L1 expression in triple-negative breast cancer. Cancer Immunol Res. 2014; 2:361-70. https://doi.org/10.1158/2326-6066. CIR-13-0127.

150. Spranger S, Spaapen RM, Zha Y, Williams J, Meng Y, Ha TT, Gajewski TF. Up-regulation of PD-L1, IDO, and $\mathrm{T}$ (regs) in the melanoma tumor microenvironment is driven by CD8(+) T cells. Sci Transl Med. 2013; 5:200ra116. https://doi.org/10.1126/scitranslmed.3006504.

151. Zingoni A, Fionda C, Borrelli C, Cippitelli M, Santoni A, Soriani A. Natural Killer Cell Response to ChemotherapyStressed Cancer Cells: Role in Tumor Immunosurveillance. Front Immunol. 2017; 8:1194. https://doi.org/10.3389/ fimmu.2017.01194.
152. Tian X, Wei F, Wang L, Yu W, Zhang N, Zhang X, Han $\mathrm{Y}, \mathrm{Yu}$ J, Ren X. Herceptin Enhances the Antitumor Effect of Natural Killer Cells on Breast Cancer Cells Expressing Human Epidermal Growth Factor Receptor-2. Front Immunol. 2017; 8:1426. https://doi.org/10.3389/ fimmu.2017.01426.

153. Jiang X, Ellison SJ, Alarid ET, Shapiro DJ. Interplay between the levels of estrogen and estrogen receptor controls the level of the granzyme inhibitor, proteinase inhibitor 9 and susceptibility to immune surveillance by natural killer cells. Oncogene. 2007; 26:4106-14. https:// doi.org/10.1038/sj.onc.1210197.

154. Rathore AS, Goel MM, Makker A, Kumar S, Srivastava AN. Is the tumor infiltrating natural killer cell (NK-TILs) count in infiltrating ductal carcinoma of breast prognostically significant? Asian Pac J Cancer Prev. 2014; 15:3757-61.

155. Vgenopoulou S, Lazaris AC, Markopoulos C, Boltetsou E, Kyriakou V, Kavantzas N, Patsouris E, Davaris PS. Immunohistochemical evaluation of immune response in invasive ductal breast cancer of not-otherwise-specified type. Breast. 2003; 12:172-8.

156. Cheng M, Chen Y, Xiao W, Sun R, Tian Z. NK cell-based immunotherapy for malignant diseases. Cell Mol Immunol. 2013; 10:230-52. https://doi.org/10.1038/cmi.2013.10.

157. Romanski A, Bug G, Becker S, Kampfmann M, Seifried E, Hoelzer D, Ottmann OG, Tonn T. Mechanisms of resistance to natural killer cell-mediated cytotoxicity in acute lymphoblastic leukemia. Exp Hematol. 2005; 33:344-52. https://doi.org/10.1016/j.exphem.2004.11.006.

158. Gyorffy B, Surowiak P, Budczies J, Lanczky A. Online survival analysis software to assess the prognostic value of biomarkers using transcriptomic data in non-small-cell lung cancer. PLoS One. 2013; 8:e82241. https://doi.org/10.1371/ journal.pone. 0082241 . 